\title{
Contribution of the swine model in the study of human sexually transmitted infections
}

Käser, Tobias; Renois, Fanny; Wilson, Heather L.; Cnudde, Thomas; Gerdts, Volker; Dillon, Jo-Anne R.; Jungersen, Gregers; Agerholm, Jørgen S.; Meurens, François

Published in:

Infection, Genetics and Evolution

Link to article, DOI:

10.1016/j.meegid.2017.11.022

Publication date:

2018

Document Version

Peer reviewed version

Link back to DTU Orbit

Citation (APA):

Käser, T., Renois, F., Wilson, H. L., Cnudde, T., Gerdts, V., Dillon, J-A. R., Jungersen, G., Agerholm, J. S., \& Meurens, F. (2018). Contribution of the swine model in the study of human sexually transmitted infections. Infection, Genetics and Evolution, 66, 346-360. https://doi.org/10.1016/j.meegid.2017.11.022

\section{General rights}

Copyright and moral rights for the publications made accessible in the public portal are retained by the authors and/or other copyright owners and it is a condition of accessing publications that users recognise and abide by the legal requirements associated with these rights.

- Users may download and print one copy of any publication from the public portal for the purpose of private study or research.

- You may not further distribute the material or use it for any profit-making activity or commercial gain

- You may freely distribute the URL identifying the publication in the public portal 


\section{Accepted Manuscript}

Contribution of the swine model in the study of human sexually transmitted infections

Tobias Käser, Fanny Renois, Heather L. Wilson, Thomas Cnudde, Volker Gerdts, Jo-Anne R. Dillon, Gregers Jungersen, Jørgen S. Agerholm, François Meurens

PII:

S1567-1348(17)30402-1

DOI: doi:10.1016/j.meegid.2017.11.022

Reference: MEEGID 3337

To appear in: Infection, Genetics and Evolution

Received date: 15 September 2017

Revised date: 18 November 2017

Accepted date: 22 November 2017

Please cite this article as: Tobias Käser, Fanny Renois, Heather L. Wilson, Thomas Cnudde, Volker Gerdts, Jo-Anne R. Dillon, Gregers Jungersen, Jørgen S. Agerholm, François Meurens, Contribution of the swine model in the study of human sexually transmitted infections. The address for the corresponding author was captured as affiliation for all authors. Please check if appropriate. Meegid(2017), doi:10.1016/ j.meegid.2017.11.022

This is a PDF file of an unedited manuscript that has been accepted for publication. As a service to our customers we are providing this early version of the manuscript. The manuscript will undergo copyediting, typesetting, and review of the resulting proof before it is published in its final form. Please note that during the production process errors may be discovered which could affect the content, and all legal disclaimers that apply to the journal pertain. 


\section{Contribution of the swine model in the study of human sexually transmitted infections}

Tobias Käser ${ }^{1}$, Fanny Renois ${ }^{2}$, Heather L. Wilson ${ }^{3}$, Thomas Cnudde ${ }^{4}$, Volker Gerdts ${ }^{3}$, JoAnne R. Dillon ${ }^{3,5}$, Gregers Jungersen ${ }^{6}$, Jørgen S. Agerholm ${ }^{7 \S}$, François Meurens ${ }^{8 \S^{*}}$

${ }^{1}$ Department of Population Health and Pathobiology, College of Veterinary Medicine, North Carolina State University, 1060 William Moore Drive, 27607 Raleigh, North Carolina, USA

${ }^{2}$ LUNAM Université, Oniris, Laboratoire d'Étude des Résidus et Contaminants dans les Aliments (LABERCA), UMR INRA 1329, 44307, Nantes, France

${ }^{3}$ Vaccine and Infectious Disease Organization - International Vaccine Centre (VIDO-InterVac), University of Saskatchewan, 120 Veterinary Road, S7N 5E3 Saskatoon, Saskatchewan, Canada

${ }^{4}$ BIOMAP, Laboratoire Biomédicaments Anti-Parasitaires, ISP, UMR INRA 1282, Université Tours, 37380 Nouzilly, France

${ }^{5}$ Department of Microbiology and Immunology, College of Medicine, University of Saskatchewan, Canada

${ }^{6}$ Section for Immunology and Vaccinology, National Veterinary Institute, Technical University of Denmark, Copenhagen, Denmark

${ }^{7}$ Section for Veterinary Reproduction and Obstetrics, Department of Veterinary Clinical Sciences, Faculty of Health and Medical Sciences, University of Copenhagen, Copenhagen, Denmark

${ }^{8}$ BIOEPAR, INRA, Oniris, La Chantrerie, 44307, Nantes, France

${ }^{\S}$ Contributed equally to this work

*Corresponding author: Email: francois.meurens@oniris-nantes.fr ; Phone: +33 2406877 02;

Fax: +33240682802.

Short Running Title: The porcine model for human sexually transmitted infections

Keywords: Pig model, Chlamydia trachomatis, Trichomonas vaginalis, Neisseria gonorrhoeae, Hepatitis viruses, Herpesviruses 


\section{ABSTRACT}

The pig has garnered more and more interest as a model animal to study various conditions in humans. The growing success of the pig as an experimental animal model is explained by its similarities with humans in terms of anatomy, genetics, immunology, and physiology, by their manageable behavior and size, and by the general public acceptance of using pigs for experimental purposes. In addition, the immunological toolbox of pigs has grown substantially in the last decade. This development led to a boost in the use of pigs as a preclinical model for various human infections including sexually transmitted diseases (STIs) like Chlamydia trachomatis. In the current review, we discuss the use of animal models for biomedical research on the major human STIs. We summarize results obtained in the most common animal models and focus on the contributions of the pig model towards the understanding of pathogenesis and the host immune response. In addition, we present the main features of the porcine model that are particularly relevant for the study of pathogens affecting human female and male genital tracts. We also inform on the technological advancements in the porcine toolbox to facilitate new discoveries in this biologically important animal model. There is a continued need for improvements in animal modeling for biomedical research inclusive STI research. With all its advantages and the highly improved toolbox, the porcine model can play a crucial role in STI research and open the door to new exciting discoveries.

\section{INTRODUCTION}

Animal models are crucial for propelling biomedical research inclusive the study of infectious diseases. Sexually transmitted infections (STIs) are a major health issue in humans and recent global surveys estimate that more than a million STIs are acquired every day, 
worldwide (Gottlieb and Johnston, 2016; Looker et al., 2015a, 2015b, 2015c; Newman et al., 2015). In 2012, an estimated 357 million new cases of infections by Chlamydia trachomatis, Neisseria gonorrhoeae, Treponema pallidum, and Trichomonas vaginalis, and 19.2 million new cases of Herpes simplex virus (HSV) type 2 occurred (Looker et al., 2015b; Newman et al., 2015). Researchers are developing vaccines against these STIs and use animal models in preclinical trials to: i) optimize vaccine formulation (antigen, adjuvant, delivery vehicle) and route of administration (e.g., intramuscular vs. mucosal); ii) determine an effective and safe vaccine dosage; and iii) assess the induced immune response to find immune correlates of protection and to detect detrimental immune responses. This preclinical development is of utmost importance since it maximizes the chances that a vaccine candidate will turn out to be protective and safe before it is applied to humans in the subsequent clinical phases. Careful selection of an appropriate animal model maximizes the chances that the results obtained in preclinical development translate into humans. For some STIs, such as Haemophilus ducreyi and genital herpesvirus infections, experimental animal models are well established, while for others this development is more challenging. Therefore, researchers are searching for new and better animal models. Besides the main animal models mice and non-human primates (NHPs), the pig has gained importance as an experimental animal model to study various human illnesses.

Mice are easy to handle with an extensive biological toolbox making them the most frequently used animal model in biomedical research. A large number of vaccine candidates have been designed and assessed in mice (Bosio et al., 2012; McShane and Williams, 2014). While these advantages are useful for the design of vaccine candidates, physiological and immunological differences between humans and mice limit their biological relevance for preclinical vaccine studies including efficacy and toxicology testing (Bosio et al., 2012; McShane and Williams, 2014). Due to the limitations of the mouse model, most vaccine 
candidates are tested in a second, biologically more relevant animal model before entering the clinical phases.

NHPs are closely related to humans and can provide biological data that is highly relevant. The downside of this close relationship to humans is that the use of NHPs for biomedical research is controversial due to their high ethical burden. As a result, animal experiments in NHPs are heavily regulated, very expensive and the availability of NHPs is a pressing concern to biomedical research which represents a significant bottleneck for vaccine development. This reality has led to an increasing demand for an affordable, accessible, and biologically relevant animal models (Gerdts et al., 2015; Lankau et al., 2014; Meurens et al., 2012). The pig combines the attributes required for such as model (Box 1) and is gaining more and more interest in biomedical research including vaccine development (Gerdts et al., 2015; Meurens et al., 2012).

Pigs were first introduced as a large animal model for biomedical research in the middle of the $20^{\text {th }}$ century (Gutierrez et al., 2015). The interest in the swine model has since then grown due to the many similarities with humans regarding its anatomy, genetic, immunology, and physiology (Lossi et al., 2016; Meurens et al., 2012; Swindle et al., 2012). Pigs are also widely available, have a manageable size and a behavior that allows for both smooth handling and easy experimental interventions. In addition, pigs are accepted as experimental animals by the general public, which may not be the case for animals such as dogs and NHPs). The biomedical toolbox for pigs has heavily increased during the last decade leading to its strongly increased popularity as a model for biomedical research and especially for preclinical vaccine studies (Gerdts et al., 2015; Meurens et al., 2012). Over the past ten years, many excellent reviews have been published related to the potential and documented success of the pig as a biomedical model for conditions in humans (Fairbairn et al., 2011; Gerdts et al., 2015; Klymiuk et al., 2016; Meurens et al., 2012; Rogers, 2016; Rogers et al., 
2008). Various studies that utilized the swine model for the study of human infectious diseases with significant contributions and potential new developments were reviewed by Meurens et al. (Meurens et al., 2012). One review addressed the use of the swine model in the study of the human chlamydiosis (Lorenzen et al., 2015b). With the current review, we present the main animal models to study human STIs and we focus on the interest and the potential of the swine model to understand and more efficiently reduce the impact of these devastating human infections.

\section{EXISTING ANIMAL MODELS FOR INFECTIOUS DISEASES}

The use of experimental animal models to study infectious diseases is necessary to improve our understanding of disease pathogenesis and to develop and test preventive and therapeutic approaches prior to their use in human clinical trials. A truly effective animal model reproduces as many aspects of the human disease under investigation as possible. Two main classification systems for animal models exist (Gerdts et al., 2015; Meurens et al., 2012). The first classification system differentiates (i) spontaneous, (ii) experimentallyinduced or (iii) transgenic models. The second system distinguishes between (i) natural or (ii) surrogate models. Logically these two classification systems are not independent and spontaneous models are usually naturally occurring while surrogate models are experimentally induced or even transgenic in nature. In natural models, animal pathogens similar to or even identical (zoonotic pathogens) to the human pathogens are used. In this case, animal and human pathogens share a high degree of similarity in their antigenicity, genetics, host cell and receptor tropism, and pathogenesis. For surrogate models, the human pathogen is administered to a permissive animal. Ideally, the human pathogen should enter the animal host via a same route, must replicate at a sufficient level and should target the same tissues and organs. However surrogate models can be difficult to establish and usually the 
disease developed in the model is milder than the disease naturally observed in the human host. When a model is selected, different parameters have to be considered to evaluate its effectiveness (Denayer et al., 2014; Lorenzen et al., 2015b) including face, predictive and target validities. Face validity assesses how well is the biology and symptoms of the disease mimicked by the selected model. Predictive validity assesses how well the effects of a treatment are mimicked by the chosen model. Target validity assesses how similar the role the target system plays in the selected model compared to what is described in humans.

\section{THE PIG AS A MODEL IN THE STUDY OF HUMAN SEXUALLY TRANSMITED INFECTIONS}

The porcine model has been used in the study of several human infectious diseases (Meurens et al., 2012) and has been subject of many reviews including those focused on using large animal models for vaccine development and testing (Gerdts et al., 2015). Very recently, the pig was used as surrogate model for emerging Zika virus which increases its potential for other diseases that affect the fetus (Darbellay et al., 2017). Pigs have also been used as a preclinical models to decipher complex human diseases, and to accelerate the development of safe and efficient therapies (Klymiuk et al., 2016; Schomberg et al., 2016). The recent development of gene editing tools further increases the potential of large animals, including pigs, to model human diseases as presented in some interesting reviews (Rogers, 2016; Whitelaw et al., 2016).

\section{THE FEMALE AND MALE PORCINE GENITAL TRACT}

The relevance of the pig as a model for human diseases is based on its similarities in regard to anatomy, physiology and immunology. In addition to these aspects, the genital microbiome and the influence of the hormonal cycle on the tissue and local immune system 
increases the complexity of studying STIs in animal models. Lorenzen et al. (Lorenzen et al., $2015 \mathrm{~b}$ ) provided a comprehensive review on the advantages and disadvantages of the porcine female genital tract for studying Chlamydia infections. The following section provides a short overview of the most relevant aspects of the porcine female and male genital systems for studying human STIs.

\section{The porcine female genital tract}

Anatomy: One major difference in the gross anatomy of the pig compared to the genital tract of women is the bicornual anatomy of the porcine uterus. In women, the genital tract consists of the vagina, a short cervix, and a uterus with a single compartment, the uterine body, from which the two Fallopian tubes arise. In pigs, the vagina is followed by a long cervix including prominent mucosal ridges (cervical pulvini), a common short body and two long horns from each of which a Fallopian tube origins (Nickel et al., 1979) (Fig. 1). This difference and others have importance in the use of the pig model to study ulcerative and non-ulcerative human pathogens targeting the genital tract at various locations such as vagina for Trichomonas vaginalis and external genitalia and lower genital tract for ulcerative pathogens like Haemophilus ducreyi, Treponema pallidum, Herpesviridae (Herpes simplex virus (HSV) types 1 and 2), and Papillomaviridae (Human papillomavirus, HPV). For instance, in the case of the infection caused by Chlamydia trachomatis and its ascension into the Fallopian tubes, the longer distance between vagina and Fallopian tubes in pigs than in humans may prevent the inoculated microorganism from entering the Fallopian tubes. At the microscopic level, the most important feature in relation to experimental infections is the location of columnar epithelial cells as they are the target cells of several STI pathogens. In women, especially in young women, columnar epithelial cells are located in the endocervix, but in pigs the cervical canal is covered predominantly by a stratified squamous epithelium in the gilt and sow and columnar epithelial cells are present within the uterus (Priedkalns and Leiser, 2006). Hence, 
to promote a successful infection of columnar epithelial cells, pigs should be administered the pathogen directly into the uterine lumen. Due to the presence of the cervical pulvini, intrauterine infection via transcervical inoculation should be performed during estrus when the cervical canal is permissive and allows catheterization. Synchronization of the porcine hormonal cycle via altrogenest (allyl trenbolone $20 \mathrm{mg}$ oral for 18 consecutive days) allows for consistent intrauterine inoculations of pigs during estrus - when cervix is opened - and is a standard procedure for catheterization during artificial insemination in commercial pig production.

Hormonal cycle: Hormones influence the presence and activity of several immune cell subsets and immune modulators. Therefore, it is crucial to understand the differences and similarities of the hormonal cycle between pigs and humans. A recent comparative review (Lorenzen et al., 2015b) (summarized in Table 1) showed closely related porcine and human hormonal cycles with small differences in the one week shorter duration of hormonal cycle in pigs and the luteinizing prostaglandin (PG) F2 $\alpha$ hormone originating from the uterus in pigs and ovaries in women. The epithelium and functional layers of the endometrium show similar cyclic changes in women and pigs (Lorenzen et al., 2015b). Interestingly, regarding immune cell infiltration in the genital mucosa, there is an influx of neutrophils in the porcine endometrium during pro-oestrus and estrus (Hussein et al., 1983; Jiwakanon et al., 2005; Kaeoket et al., 2002). While the hormonal cycle is very similar, there is one major difference in their physiology. In contrast to women, pigs do not undergo endometrial sloughing (menses), which may change the course of infection compared to what occurs in women under naturally occurring infections.

Microflora: Another important difference is the acidic vaginal $\mathrm{pH}$ and the flora, which is dominated by lactobacilli in women, compared to a neutral $\mathrm{pH}$ and a mixed non-lactobacillus flora in pigs (Bara et al., 1993; Farage et al., 2010; Mather et al., 1977; Zhou et al., 2004). 
These differences in flora may not be of significance in experimental studies if inoculation is done directly into the uterine lumen.

\section{The porcine male genital system}

Most studies using pigs as a model of STIs in humans have focused on infections in females. However, due to the general similarities between humans and pigs (Lossi et al., 2016; Swindle et al., 2012), boars can also be interesting as an animal model in the study of human STI various aspects (see Table 2). For males, there are species-specific differences that one must be aware of, such as differences in the environment, external morphology and anatomy of the porcine penis and prepuce.

While the human penis is characterized as a soft tissue with considerable amounts of erectile tissue, the porcine penis is of the fibroelastic type consisting mainly of connective tissue with limited amount of erectile tissue. So even erected, the boar penis maintains its shape as a hard, thin, tapering 'stick'. The anterior of the boar penis is twisted counterclockwise, while the posterior part is coiled as a sigmoid flexure. Straightening of the flexure is responsible for erection, while only a flat plexus of veins at the glans of the penis becomes distended (Eurell and Frappier, 2006; König and G, 2009; Lossi et al., 2016; Nickel et al., 1979; Silverthorn, 2007). The prepuce is much longer than the penis and is covered by hairs at the tip. A diverticulum of considerable size is present in the dorsal wall of the prepuce, e.g. in

an adult Landrace boar it may contain $135 \mathrm{~mL}$ of epithelial debris and urine and the opening may be passable for two fingers although often closed by mucosal folds (Fig. 2). The prepuce is covered by a stratified squamous epithelium (Nickel et al., 1979; Wrobel and Bergman, 2006). Boars urinate inside the preputial cavity and the external genital tract is located on the ventral surface of the abdomen causing a risk for heavy exposure to environmental contamination. This may create an environment of the porcine prepuce that is probably very 
different from the prepuce of men and may make boars unsuited as models of STIs located to these structures.

In man, several sexually transmitted pathogens such as C. trachomatis, Neisseria gonorrhoeae, and Mycoplasma genitalium localize to the urethra, which in the membranous and penile parts is covered by a stratified or ciliated pseudostratified columnar epithelium (Krause, 2005). In the boar, these parts are covered by a transitional epithelium (Wrobel and Bergman, 2006). Also, the size of the accessory glands differs, especially because boars have extremely large bulbourethral glands (Fig. 2) (Krause, 2005; Nickel et al., 1979; Silverthorn, 2007).

\section{CURRENT MODELS FOR STIS IN HUMANS AND CONTRIBUTIONS OF THE PORCINE MODEL}

The frequent STIs affecting human populations are caused by bacteria, parasites, and viruses (CDC 2017, https://www.cdc.gov/std/default.htm). The main bacterial families causing STIs are Chlamydiaceae, Mycoplasmataceae, Neisseriaceae, Pasteurellaceae, and Spirochaetaceae with $C$. trachomatis, $M$. genitalium, $N$. gonorrhoeae, and $T$. pallidum as their most important species in term of frequency. Their high prevalence coupled with increasing levels of antibiotic resistance, especially in case of $N$. gonorrhoeae and Mycoplasma genitalium, has made the quest for currently unavailable effective vaccines urgent (Unemo et al., 2017). The most important parasite is $T$. vaginalis and the major RNA and DNA viruses belong to the families Flaviviridae (Hepatitis $\mathrm{C}$ virus, $\mathrm{HCV}$ ), Hepadnaviridae (Hepatitis B virus, HBV), Herpesviridae (HSV-1 and HSV-2), Papillomaviridae (HPV), and Retroviridae (Human immunodeficiency virus 1 and 2, HIV-1 and -2). 
Many animal models provide insights in the pathogenesis of human STIs to facilitate the development of vaccines and therapeutics. The following sections address available animal models for each of these pathogens including the most common rodent and primate models as well as alternative animal models. At the end of each section, we will address how swine can contribute as a large animal model for the study of the respective pathogens.

\section{Chlamydia trachomatis}

Chlamydia trachomatis is the most common sexually transmitted bacterium worldwide [World Health Organization, 2012, ISBN: 9789241503839]. Infection is often asymptomatic. Ascending infections into the Fallopian tubes of women may cause pelvic inflammatory disease, tubal infertility, and ectopic pregnancy (Unemo et al., 2017). The majority of animal studies have been carried out using mice, guinea pigs and NHPs (for a review see (Miyairi et al., 2010)) (Fig. 3). The natural mouse model has been developed with C. muridarum, the murine Chlamydia species. Vaginal C. muridarum infections are relatively robust and can ascend to the upper genital tract and cause Fallopian tube lesions with subsequent complications (de la Maza et al., 1994; Shah et al., 2005). However, there are significant differences between $C$. muridarum and $C$. trachomatis and these hamper drawing parallels with human $C$. trachomatis infections. Contrary to $C$. muridarum, which has only one serovar, $C$. trachomatis has 18 substantial allelic variations of the dominant surface protein major outer membrane protein (MOMP), while $C$. muridarum has a single allele (Rank and Whittum-Hudson, 2010). However, the main disadvantage of the mouse model is its different sensitivity to IFN- $\gamma$. While $C$. trachomatis can avoid IFN- $\gamma$-induced tryptophan starvation by expressing a tryptophan synthase, $C$. muridarum is not able to produce this enzyme (Nelson et al., 2005), probably as a consequence of a different effect of IFN- $\gamma$ on human and murine epithelial cells. Contrary to human epithelial cells, murine epithelial cells 
do not express indoleamine 2,3-dioxygenase following IFN- $\gamma$ exposure but instead have redundant mechanisms using nitric oxide synthase and others (Ramsey et al., 1998). Mice can be infected with $C$. muridarum as well as $C$. trachomatis, although infections with the later are usually mild and mice lacking functional T-cells are able to clear $C$. trachomatis infections (Tuffrey et al., 1982). Coers et al. generated Immunity Related GTPase (IRG) knockout mice in order to overcome this limitation. These knockout mice developed a transient high bacterial burden upon intrauterine inoculation with the C. trachomatis serovar L2. Clearance of this infection was at least partly driven by CD4 $4^{+} \mathrm{T}$ cells (Coers et al., 2011).

Chlamydia trachomatis infections do not ascend to the Fallopian tubes in mice, a key aspect for studying chlamydial pathogenesis (Farris and Morrison, 2011). Therefore, sequelae of $C$. trachomatis infection are induced in mice by direct inoculation of the upper genital tract. This inoculation route has one disadvantage in modeling natural human infections: "During natural human infection, the time required for ascension of the bacterium to the Fallopian tubes may allow for homing of protective memory T-cells, leading to a decrease in the infectious inoculum and consequent damaging inflammation at this vulnerable tissue site" as stated by Darville and Hiltke (Darville and Hiltke, 2010). Furthermore, other differences could hamper the translation of findings from mice to humans, such as the hormonal treatment to enhance infection, different size of the hosts limiting the collect of samples, and the higher vaginal $\mathrm{pH}$ of 6.6 in mice compared with 3.5-5 in women.

Guinea pigs are another natural model frequently used to study chlamydial infections, generally with $C$. caviae as the infective agent. Intravaginal $C$. caviae inoculation of guinea pigs leads to ascension through self-limiting infections which appear to resemble $C$. trachomatis infections in women (Rank et al., 1982). In a recent study, de Jonge et al. introduced an alternative guinea pig model using $C$. trachomatis, which also showed indications of ascending infections (de Jonge et al., 2011). However, guinea pig models have 
drawbacks such as a smaller size than humans. Another issue is the limited molecular toolbox in guinea pigs which has likely contributed to the low number of studies on chlamydial genital tract infection, although studies on $C$. caviae genital infections of guinea pigs date back to 1972 (Mount et al., 1972).

NHPs are close relatives to humans and have also been used as animal models for $C$. trachomatis infection. Intracervical inoculation with human $C$. trachomatis serovars can result in long-term (up to 15 weeks) infections in pig-tailed macaques (Macaca nemestrina) (Wolner-Hanssen et al., 1991) and repeated inoculations can result in the ascension of infection to the Fallopian tubes (Patton, 1985). However, NHP models suffer from the previously mentioned ethical problems and are expensive (Meurens et al., 2012).

The pig is the natural host to $C$. suis, a very prevalent pathogen with a high similarity to C. trachomatis (Schautteet and Vanrompay, 2011). Genital C. suis infections can lead to similar pathological changes and disease outcomes as $C$. trachomatis infections and have been associated with reproductive disorders as reduced conception rates and inferior semen quality. Importantly, recent studies demonstrate a zoonotic potential for $C$. suis (Dean et al., 2013; De Puysseleyr et al., 2017). Due to the close relationship between $C$. trachomatis and $C$. suis and the similar disease outcomes in swine, researchers have started to use the pig as a large animal model to study $C$. trachomatis infections and for developing and testing $C$. trachomatis vaccines using either conventional pigs or minipigs (Bøje et al., 2016; Käser et al., 2017; Lorenzen et al., 2017; Schautteet et al., 2012, 2011a).

The minipig model: Several studies using vaginal inoculation with the $C$. trachomatis SvD/UW-3/Cx strain (ATCC® VR-885 ${ }^{\mathrm{TM}}$ ) in sexually mature female Göttingen minipigs during estrus were developed and characterized as a porcine model of genital chlamydiosis in women for use in vaccine studies (Bøje et al., 2016; Lorenzen et al., 2017).

\section{Chlamydia trachomatis infection via deep vaginal inoculation:}


A self-limiting infection was induced following deep vaginal inoculation of $1.8 \times 10^{9}$ inclusion forming units (IFUs). The minipigs were followed for up to seven days during which the infection declined with only a few samples being slightly positive by quantitative polymerase chain reaction (qPCR) for chlamydial $16 \mathrm{~S}$ rRNA on day 7. C. trachomatis was found by qPCR in both the uterus and Fallopian tubes of individual minipigs, but the infection was associated with only a mild inflammatory response limited to the cervico-vaginal mucosa. As determined by immunohistochemistry (IHC), replication was limited and confined to the cervico-vaginal epithelium, where it was associated with cyclooxygenase- 2 and interleukin- 8 expression (Erneholm et al., 2016). Similar rapid clearance was observed in non-vaccinated control minipigs inoculated with either $3.9 \times 10^{9}$ IFUs (Bøje et al., 2016) or $5 \times 10^{9}$ IFUs (Lorenzen et al., 2015a) as part of vaccination studies. Significant levels of infection were not found beyond 3 days after inoculation in neither of the studies and C. trachomatis was not found in the uterus and the Fallopian tubes at necropsy performed 15 days after challenge (Lorenzen et al., 2015a).

\section{Chlamydia trachomatis infection via intrauterine and transcervical inoculation:}

In an attempt to establish a longer lasting infection by inoculating the bacteria at a site where columnar epithelial cells were present, Lorenzen et al. (Lorenzen et al., 2017) performed intrauterine inoculation during laparotomy using a dose of either $1 \times 10^{5}$ or $1 \times 10^{8}$ IFUs as well as a transcervical challenge using a dose of $1 \times 10^{9}$ IFUs. The rationale behind inoculation directly into the uterine lumen was the absence of columnar epithelial cells in the vagina and cervix of minipigs and the longer cervical canal with mucosal folds, which may have prevented sufficient numbers of bacteria to have reached the uterine mucosa in the previous studies (Bøje et al., 2016; Erneholm et al., 2016; Lorenzen et al., 2015a). The transcervical challenge during estrus induced an infection in all (8/8) inoculated animals up to seven days post inoculation. A dose of $1 \times 10^{5}$ IFUs using laparotomic intrauterine inoculation 
proved insufficient to establish an infection, but the high doses established an infection with a higher bacterial load than following vaginal inoculation $(\approx 2 \log$ units $)$ and an infection that lasted for up to seven days. Furthermore, the infection was associated with significant acute uterine suppurative inflammation and Chlamydia replication in columnar epithelial cells was shown by IHC in some minipigs. Intrauterine inoculation via laparotomy during estrus was short (up to 5 days) and self-curing but during diestrus this infection induced a long-term infection until the end of the study (10 days). This difference can be explained by the higher activity of the uterine mucosal innate immune system of pigs during estrus (Erneholm et al., 2016; Lorenzen et al., 2015b).

\section{Conclusions:}

Based on these findings, it is recommended that minipigs should be inoculated either transcervically during estrus, when cervix is opened, with $1 \times 10^{9}$ IFUs or directly into the uterine lumen via laparotomy during diestrus with $1 \times 10^{8}$ IFUs to facilitate establishment of a longer lasting infection. However, laparotomy is complicated by the anatomy and constriction of the cervical canal during diestrus.

The minipig model needs to be further developed, especially to mimic long-term infections and development of chronic lesions in the Fallopian tubes as seen in cases of chronic genital chlamydiosis in women.

The conventional pig model: Conventional pigs have been used for studying $C$. trachomatis infections since 2005 (Schautteet et al., 2012, 2011a, 2011b; Vanrompay et al., 2005).

$\underline{\text { Infection and basic immune response analysis upon } C \text {. trachomatis vaccination and challenge: }}$ Based on studies on pigs inoculated intravaginally with $10^{8}$ IFUs $C$. trachomatis strain E Bour and 468 it was concluded that both strains ascended to the Fallopian tubes, induced pathology, and triggered a humoral immune response (Vanrompay et al., 2005). In 2011, two $C$. trachomatis trials in pigs were performed to test two recombinant protein vaccines and a 
MOMP-based DNA vaccine. Upon intravaginal challenge with $10^{8}$ IFUs $C$. trachomatis E Bour, Schautteet et al. (Schautteet et al., 2011a, 2011b) reported less severe macroscopic lesions and decreased $C$. trachomatis replication and vaginal excretion in the group vaccinated by the MOMP-based DNA vaccine. The recombinant protein vaccine using PmpG as antigen also induced partial protection to $C$. trachomatis infection based on scoring of lesions. Protection did not correlate with a humoral immune response and T-cell immune response was not investigated (Schautteet et al., 2011a, 2011b). In 2012, the same group performed another vaccination trial comparing mucosal vs. intradermal DNA immunization. In comparison to intradermal vaccination, the mucosal vaccination route induced globally a stronger immune response but still only a partial protection against $C$. trachomatis challenge. Higher serum IgA levels and T-cell priming correlated with protection, although the authors did not test for $C$. trachomatis-specific T-cells since in vitro restimulation was performed using Concanavalin A instead of chlamydial antigens (Schautteet et al., 2012).

Deciphering the T-cell immune response to $C$. trachomatis and $C$. suis infection:

The induction of Chlamydia-specific T-cells by $C$. suis and C. trachomatis was focus of a recent study by Käser et al. (Käser et al., 2017). In that study, conventional pigs were infected transcervically with $10^{8}$ IFUs $C$. suis (strain S45) or $C$. trachomatis (strain E Bour). The authors followed the infection for 21 days and analyzed chlamydial titers in vaginal swabs and genital tissue at necropsy. The induction of the humoral immune response was analyzed by determining neutralizing antibody levels in blood, and the activation and cytokine production of different T-cell subsets in blood (time-course) and the draining lymph nodes (at necropsy) using polychromatic (multi-color) flow cytometry (pFCM). C. suis and $C$. trachomatis were detectable in vaginal swabs until 21 days and 7 days post infection, respectively. Analyzing chlamydial infection in the upper genital tract at necropsy (uterine horn flushes and tissue with gross lesions) showed that the infection was still ongoing in this 
location in 3/5 (C. suis) and 4/5 (C. trachomatis) infected animals until 21 days post infection. While only infection with $C$. suis induced neutralizing antibodies, both Chlamydia species induced a CD4 ${ }^{+} \mathrm{T}$-cell immune response in most animals with IFN- $\gamma$ single-, and IFN- $\gamma / \mathrm{TNF}-$ $\alpha$ double-producing $\mathrm{CD}^{+}{ }^{+} \mathrm{T}$-cells as main responders (Käser et al., 2017). The detected IFN- $\gamma$ single-, and IFN- $\gamma / \mathrm{TNF}-\alpha$ double-producing $\mathrm{CD}^{+}{ }^{+}$-cells have been reported previously to be the best correlates of protection against $C$. muridarum infection (Yu et al., 2011).

\section{Conclusions:}

The conventional pig model requires further establishment to provide a more consistent and resilient infection with $C$. trachomatis to induce a stronger immune response. Nevertheless, the performed studies demonstrate the potential of the pig to study $C$. trachomatis infections inclusive of vaccination studies. The current improvements in the porcine immunological toolbox provide a sensitive pathogen detection system combined with an in-depth analysis of the induced immune response including neutralizing antibody levels and multifunctional T-cells.

\section{Haemophilus ducreyi}

Haemophilus ducreyi is the etiologic agent of chancroid, a sexually human transmitted disease characterized by painful sores on the genitalia consecutive to the development of ulcerating cutaneous lesions. The disease is a lot less frequent today than it was before and far less prevalent than other diseases presented in this review (González-Beiras et al., 2016). However, because the pig model has been considerably used to study $H$. ducreyi (Afonina et al., 2006; Fulcher et al., 2006; Hobbs et al., 1995), it has been chosen to present it here too. Indeed, studies have shown evidences that the histopathology of the lesions in the ear skin pig model closely resembles that of human chancroid (Hobbs et al., 1995) and that the swine immunology and skin structure closely resemble their human counterparts (Summerfield et 
$a l ., 2015 b)$. The temperature-dependent rabbit model has also been used to obtain data on associated virulence factors and immuno-pathogenesis of chancroid $H$. ducreyi infections (Desjardins et al., 1996, 1995). Studies using this model demonstrated that infected wholecells, crude outer membrane protein mixtures or purified vaccine proteins could induce an immune protection against $H$. ducreyi infections. However, the antibodies produced did not show bactericidal or opsonophagocytic capacities (Desjardins et al., 1996, 1995). Finally, some studies were also performed using NHPs (i.e., Macaca mulatta) (Sturm, 1997; Totten et al., 1994). These NHPs had the advantage of allowing the assessment of some strains which were not virulent in the rabbit model even if pathogenic for humans (Sturm, 1997).

Most porcine data in the study of $H$. ducreyi pathogenesis were generated using the surrogate ear skin swine model developed in crossbred (Yorkshire, Landrace, Hampshire, and Duroc Cross) or purebred (Landrace) conventionally reared swine (Hobbs et al., 1995). This swine model established which immune cell types were involved in $H$. ducreyi infection (Hobbs et al., 1995). Analysis by Western blots of $H$. ducreyi proteins presented in swine serum after 2 weeks of inoculation demonstrated a response characterized by increased concentrations of IgG antibodies targeting H. ducreyi antigens (Hobbs et al., 1995). Other studies tried to identify the mechanism of entry, colonization steps and pathogenesis, and to define factors present into immune serum that conferred protection against $H$. ducreyi. These studies demonstrated that $H$. ducreyi infection requires two TonB-dependent receptors - the hemoglobin receptor $(\mathrm{HgbA})$ and a receptor for free heme (TdhA) - and that the NcaA outer membrane protein is required for collagen binding (Afonina et al., 2006; Fulcher et al., 2006). Anti-HgbA IgG was able to block hemoglobin binding to the HgbA receptor showing the importance of $\mathrm{HgbA}$ in the development of vaccine candidates against chancroid (Afonina $e t$ al., 2006; Fulcher et al., 2006). Based on these studies, the swine model appears interesting to 
answer questions related to $H$. ducreyi pathogenesis, to perform therapeutic trials, and to develop vaccine candidates.

\section{Mycoplasma genitalium}

Mycoplasma genitalium is a common STI agent causing urethritis in both men and women, and cervicitis and pelvic inflammation in women. This emerging bacterium was first described in the 1980s in men with non-gonococcal and non-chlamydial urethritis (Tully et al., 1981). Since then, others studies have confirmed the involvement of M. genitalium in 10$35 \%$ of human reproductive tract non-gonococcal and non-chlamydial inflammatory diseases including urethritis in men, and cervicitis, pelvic inflammatory disease, and infertility in women (Jensen et al., 2016). Its prevalence is increasing and rivaling that of $C$. trachomatis. Furthermore, it is resistant to antibiotics and treatment options are becoming more limited (Manhart, 2017). Animal studies are needed to comprehensively study the pathogenesis of $M$. genitalium, particularly its contribution to ascending genital tract infections of women (Wiesenfeld and Manhart, 2017). To date, few studies have been conducted to establish an animal model to obtain better knowledge of the $M$. genitalium pathogenesis. The literature includes mainly studies using several NHP infection surrogate models including chimpanzees (Pan troglodytes - not allowed anymore) and pig-tailed macaques to investigate pathogenesis and host responses (Taylor-Robinson et al., 1987; Wood et al., 2017).

NHP studies: $M$. genitalium infection established classically by the urogenital route induces clinical manifestations in pig-tailed macaques similar to the ones observed in humans with a large number of polymorphonuclear leukocytes infiltrating the genital tract (Wood et al., 2017). In addition a specific serum antibody response could be demonstrated further proving host susceptibility (Wood et al., 2017). However, not all NHPs are susceptible to $M$. genitalium infection, including rhesus monkeys (Macaca mulatta) whose vaginal mucosa 
does not allow bacterium colonization, thereby preventing ascending infection (TaylorRobinson et al., 1987).

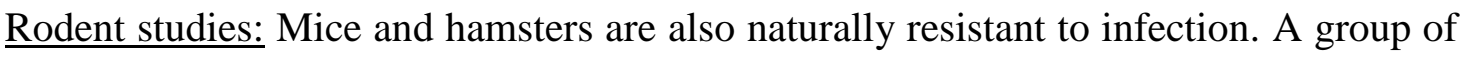
researchers has developed a female mouse model in which mice are treated with estradiol or progesterone at 7 days and at 1 day prior to $M$. genitalium type G37 or M2300 strain inoculations (McGowin et al., 2010). This model has been able to demonstrate a causal association of $M$. genitalium with reproductive disease by upper genital tract infection following vaginal exposure (McGowin et al., 2010).

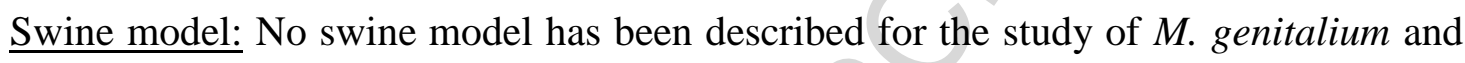
since this bacterium is very restricted to a small number of primates, the opportunity to develop a new model in the pig seem limited and would need further assessment.

\section{Neisseria gonorrhoeae}

Neisseria gonorrhoeae is the second most prevalent bacterial STI globally causing the disease gonorrhea (Unemo et al., 2017). It is an exclusively human pathogen which causes considerable morbidity and occasional mortality through untreated ectopic pregnancy worldwide. Up to $50 \%$ of cases may be asymptomatic and females are disproportionately affected because of the consequences of untreated or undetected disease (Hill et al., 2016) including pelvic pain caused by ascending genital tract infections, pelvic inflammatory disease, occlusion of the Fallopian tubes due to inflammation and ectopic pregnancy. There is no vaccine for gonorrhea but the need has become urgent as antibiotic resistance has become widespread and threatening the ability to cure the infection. The organism has been studied in various animal models including NHPs, rabbits, guinea pigs, mice, and chicken embryos (Arko, 1989). Historically, the main issue with these models was the presence of several host restrictions. In mice, the use of estradiol reduced this limitation by an unknown mechanism 
which has led to their use as a surrogate host for $N$. gonorrhoeae (Jerse et al., 2011). Estradiol-treated mice are now the most common animal model used for studying gonococcal infections. Nevertheless, important differences exist between the genital tract of women and female mice thereby limiting the use of the mouse as an $N$. gonorrhoeae animal model. The vaginal $\mathrm{pH}$ in female mice is higher than the human vaginal $\mathrm{pH}$, mostly due to differences in resident microbial populations and mice do not experience menstrual bleeding, which would bring hemoglobin, proteases, and various serum factors into the lumen of the reproductive tract (Jerse et al., 2011) (see Table 1).

Several host restrictions have been described for $N$. gonorrheae and complicate the establishment of animal models (Jerse et al., 2011; Ngampasutadol et al., 2008). These host restrictions include, for instance, lack of human CD46 counterpart in some species, which can serve as a N. gonorrhoeae pilus receptor (Jerse et al., 2011; Kallstrom et al., 1997; Källström et al., 2001), human CR3 integrin counterpart (Edwards et al., 2002), and human carcinoembryonic antigen cellular adherence molecules (CEACAMs) 1, 5, and 6 counterparts to which the phase variable opacity (Opa) proteins bind and CEACAM3, through which Opamediated uptake by neutrophils occurs without opsonization (Jerse et al., 2011; Sadarangani et al., 2011). A better understanding of host restrictions through the use of the transgenic mice such as CEACAM1 transgenic mice (Gu et al., 2010) and the identification of the mechanism behind the estradiol treatment making female susceptible to the infection are needed.

Although N. gonorrhoeae is an obligate human pathogen, there are species of the Neisseriaceae that are able to infect pigs. A pig-specific strain was recognized when five strains of an unusual Gram-negative, coccobacillus-shaped bacterium were isolated from the lung and heart of pigs with pneumonia and pericarditis and subjected to comparative $16 \mathrm{~S}$ rRNA gene sequencing (Vela et al., 2005). Results showed that the strains were phylogenetically highly related to each other and were related to the family Neisseriaceae 
(Vela et al., 2005). On the basis of both phenotypic and phylogenetic evidence, the isolates from pigs were classified as a novel genus and species within the family Neisseriaceae, named Uruburuella suis. Despite being identified in 2005, no studies have been published indicating how widespread U. suis is in the pig population around the world, how it is transmitted, whether it causes infection and whether it acts as an STI in pigs or other species. Such studies might assist in understanding $N$. gonorrhoeae transmission and infection dynamics in humans.

Limited research has been performed to establish that porcine cells can be infected with $N$. gonorrhoeae. Using ex vivo porcine vaginal mucosa (PVM) as a tissue model Breshears et al. (Breshears et al., 2015) determined that human clinical isolates of $N$. gonorrhoeae could colonize these cells and form biofilms. The PVM mucosal explants were inoculated with $\sim 10^{4}$ CFUs/explant of $N$. gonorrhoeae which then grew to $\sim 1.1 \mathrm{x}$ $10^{7}$ CFUs/explant $\left(\sim 4.2 \times 10^{7} \mathrm{CFUs} / \mathrm{mL}\right)$ with peak growth at $24-48 \mathrm{~h} . \mathrm{N}$. gonorrhoeae grew well under aerobic conditions but they grew poorly under anaerobic conditions and growth was optimal on the PVM when the underlying media was at $\mathrm{pH} 5.5-6.5$. PVM colonized with $N$. gonorrhoeae exhibited robust biofilm development within $24 \mathrm{~h}$ and showed a thick biofilm covering the majority of the explant after $48 \mathrm{~h}$. Epithelial cells visible between patches of $N$. gonorrhoeae biofilm were alive (Breshears et al., 2015) which indicates that at least ex vivo, N. gonorrhoeae could colonize, grow and form biofilms on pig vaginal mucosa. Researchers from the Wilson and Dillon laboratories have isolated primary porcine genital tract epithelial cells to establish whether they can be infected by N. gonorrhoeae (Wilson and Dillon, unpublished data). $N$. gonorrhoeas FA1090 adhered to primary pig genital tract epithelial cells after $2 \mathrm{~h}$ (Wilson and Dillon, unpublished data) and further research is being performed to establish invasion and growth of the bacteria. Preliminary data also showed that the porcine cervical and uterine mucosa have abundant expression of the CR3 (CD11b/CD18) 
gene but that the primary genital tract epithelial cells have negligible expression for this receptor (Edwards et al., 2001). We are currently investigating whether culturing the primary cells with estrogen impacts CR3 expression.

\section{Treponema pallidum}

Syphilis, a bacterial STI caused by T. pallidum subspecies pallidum, results in the establishment of a persistent and recurrent infection and is implicated in substantial morbidity and mortality (Hook, 2017). The infection occurs globally in human populations and accounts for more than 5 million new cases every year (Hook, 2017). The natural course of untreated syphilis progresses through successive stages including primary, secondary, latent, and tertiary manifestations. The primary manifestations are characterized by an ulcerative lesion at the port of entry. In men, a painless ulceration (chancre) is most often seen on the distal penis whereas in women, lesions in the vagina, cervix, rectum, perirectally, or in the mouth are most prevalent (Hook, 2017). Humans are the only natural host for T. pallidum subspecies pallidum, which restricts the use of animal models. Furthermore, it is slowly growing bacterium that cannot be cultured. An in vitro model with the invasion of tissues by pathogenic T. pallidum has been developed but is not used anymore (Riviere et al., 1989). To date, rabbits are the only mammal to develop naturally-occurring syphilis caused by $T$. paraluis-cuniculi, a bacterium closely related to $T$. pallidum subspecies pallidum with genomic sequence similarity near 99\%, antigenic cross reactivity and similar symptoms (Peng et al., 2015; Strouhal et al., 2007). Consequently, the natural rabbit model has been used to investigate pathogenesis and immunity of human syphilis or to develop therapeutic approaches (Morgan et al., 2002; Peng et al., 2015; Tantalo et al., 2005). The guinea pig model has also been used to study the pathogenesis and the development of the adaptive immune response to T. pallidum (Wicher et al., 1999). Other animal models such as guinea 
baboons (Papio papio) have also been reported to be sensitive to $T$. pallidum subspecies pertenue with clinical manifestations ranging from being asymptomatic to severe skin and mucous membranes ulcerations (Harper and Knauf, 2013). This subspecies is known to cause yaws in humans. The infection has a chronic course and is transmitted by direct contact but yaws can be considered as a STI. Yaws is the most frequent of the tropical endemic treponematoses. Infection by T. pallidum subspecies pertenue causes a skin infection, which can then spread and produce lesions in the deeper structures, in particular bone, by contiguity. Yaws is not a deadly disease, but it is painful, disfiguring, and those who suffer from it are socially stigmatized. Today, there is no absolute animal model to directly study the pathogenesis and the immune response to human syphilis or to test therapeutic approaches or vaccine candidates against this bacterium.

For this bacterium, the swine model has a poor potential so far. Treponema spp. are very adapted to their specific host and, in the pig, Treponema pedis are not associated with genital lesions but rather ear necrosis and shoulder ulcers (Svartström et al., 2013).

\section{Trichomonas vaginalis}

Also known as urogenital trichomoniasis, the anaerobic, flagellated protozoan parasite Trichomonas vaginalis causes non ulcerative vaginitis in women and urethritis in men (Kissinger, 2015). T. vaginalis infection is the most prevalent non-viral STI in the world and there are more cases of $T$. vaginalis infections than $C$. trachomatis, $N$. gonorrhoeae, and $T$. pallidum infections combined (Gottlieb and Johnston, 2016; Kissinger, 2015; Newman et al., 2015; Satterwhite et al., 2013). Most studies about trichomoniasis animal models have been carried out using pig-tailed macaques and mice (Abraham et al., 1996; Corbeil, 1995; Meysick and Garber, 1992; Nogal-Ruiz et al., 2005, 2003; Nogal Ruiz et al., 1997; Smith and Garber, 2015). In the last years murine models were mainly used to improve our knowledge 
of host-parasite relationships, mechanisms of pathogenesis, parasite virulence factors, and parasite-induced immune response. More recently the natural bovine animal model -based on T. foetus, a trichomonas species very similar to $T$. vaginalis naturally infecting bovine- has been reviewed showing some interest in the study of parasite-induced immune response (Chapwanya et al., 2016). Even more recently, several teams have used non-human primate models (pig-tailed macaques) to assess new preventive treatments against $T$. vaginalis infection and to gain insights in the understanding of HIV and C. trachomatis co-infections (Henning et al., 2014; Makarova et al., 2017; Radzio et al., 2016). Interestingly, reports demonstrated that a single $T$. vaginalis inoculation could result in persistent infection in the pig-tailed macaque. In 2015, for the first time, experiments were carried out using PVM (surrogate model) to evaluate non-conventional treatments against $T$. vaginalis infection demonstrating an interest for the pig model in the study of this important STI (Pradines et al., 2015).

\section{Hepatitis C virus}

For a long time, research on human $\mathrm{HCV}$ has been hampered by the lack of an appropriate animal model. Most research has been carried out in the chimpanzee (Pan troglodytes) model, with important limitations in terms of ethics, small sample sizes, high costs, and genetic heterogeneity (Mesalam et al., 2016), and in the horse model with similar limitations too (Ramsay et al., 2015). Recent models involving chimeric mice with humanized livers and rodent species such as the deer mouse (Peromyscus maniculatus) have improved the situation (Mesalam et al., 2016; Vandegrift et al., 2017). The deer mouse natural model is particularly attractive with the recent discovery of a $\mathrm{HCV}$ homolog in this species (Kapoor et al., 2013). These mice are available commercially, develop a spontaneous disease very similar to $\mathrm{HCV}$ hepatitis and can serve as natural model to inform about various aspects of this 
human disease (Vandegrift et al., 2017). There is no pig model to study human HCV infection.

\section{Hepatitis B virus}

Developing animal models for the study of viral hepatitis has always been challenging. Besides humans only chimpanzees have so far been shown to be natural hosts of HBV (Protzer, 2017). Other mammals such as small shrew mice (Soricidae sp.) are also permissive to the virus but at a very low level, which restricts their use as experimental models (Allweiss and Dandri, 2016). Surrogate models have also been developed in Pekin ducks and woodchucks (groundhog [Marmota monax]). Unfortunately, the disease pathogenesis in these species is drastically different limiting their use (Allweiss and Dandri, 2016). However, in vitro models are improving and very recently macaque and pig hepatocytes susceptible to HBV were reported, opening the door to the development of new animal models (Lempp et al., 2017). Lempp et al. (Lempp et al., 2017) showed that in macaque and pig hepatocytes, the sodium taurocholate cotransporting polypetide (NTCP) is the key host factor limiting HBV infection. Complementation of dog, mouse and rat hepatocytes with human NTCP made them susceptible to hepatitis D virus (HDV), but not to $\mathrm{HBV}$, demonstrating the requirement of supplementary $\mathrm{HBV}$-specific factors while macaque and pig hepatocytes became fully susceptible to HBV with the same modification (Protzer, 2017). This observation in macaque and pig paves the way to the development of new immunocompetent infection models supporting the full HBV life cycle (Protzer, 2017).

The recent finding that porcine hepatocytes expressing NTCP became susceptible to HBV replication has opened the door to the development of a surrogate porcine model to study this important human pathogen (Lempp et al., 2017). So far, obtained in vitro results are 
promising and further research is required to fully appreciate the potential of the pig as a relevant surrogate model in the study of HBV pathogenesis and host/pathogen interactions.

\section{Herpesviruses 1 and 2}

Nine herpesviruses are described in humans (Pellett and Roizman, 2013) with the best known of these double-stranded DNA viruses being HSV-1 and its "cousin" the HSV-2 (Roizman et al., 2013). HSV-1 is mainly transmitted by oral contact to cause disease in or around the mouth while HSV-2 is almost exclusively sexually transmitted, inducing ulcerative lesions in the lower genital tract and sometimes cervix (Roizman et al., 2013). It is estimated that 417 million people aged 14-49 were infected worldwide in 2012 (Looker et al., 2015c). However, HSV-1 can also be transmitted to the genital tract through oro-genital contacts and accounts for half of new cases in developed countries (Aravantinou et al., 2017). Guinea pig and mouse surrogate models have been used both for HSV-1 and HSV-2 mucosal infections (Kollias et al., 2015; Parr and Parr, 2003). In guinea pigs, continual recurrences of the lesions were observed but the isolation of HSV from the lesions was sometimes challenging (Kollias et al., 2015). A cotton rat (Sigmodon hispidus) model has also been shown to develop recurrent lesions (Yim et al., 2005). However, this model is still less characterized than the guinea pig model. More recently, an experimental surrogate model has also been developed in rhesus macaques (Macaca mulatta) for the study of genital HSV-1 infection (Aravantinou et al., 2017).

The main herpesvirus infecting pigs is Suid herpesvirus 1 (SuHV-1), an infection causing Aujeszky's disease (Pellett and Roizman, 2013). This virus is a member of the genus Varicellovirus in the Herpesviridae family as HSV-1 and HSV-2. In piglets, Aujeszky's disease starts as an acute inflammation of the upper respiratory tract and then progresses to fatal encephalomyelitis (Wittmann and Rziha, 1989). Some pigs can also develop vesicular 
lesions around the mouth, nose, and conjunctiva very similar to symptoms observed with HSV-1 infection in humans. Growers/finishers and adult pigs may only experience respiratory disease as natural transmission of the virus occurs through the oronasal route (Wittmann and Rziha, 1989). Moreover, the virus is also transmitted by mating and embryo-transfer and can impact reproduction (Wittmann and Rziha, 1989). However, genital lesions are usually not described and further research would be required to fully appreciate the potential of SuHV-1 as a model to study the pathogenesis of genital HSV infection and the host immune response it can induce.

\section{Human papillomavirus}

Human papillomaviruses, potentially causing genital warts and even -if not treatedcervical cancer, have been intensively studied and currently more than 120 different HPV types have been reported (Bernard et al., 2010; Howley et al., 2013). The species-specific nature of papillomaviruses has prevented adaptation of authentic HPV infections to experimental animal models. However, significant discoveries in the understanding of papillomaviruses pathogenesis have been carried out using cattle, dog, NHP, and rabbit (Sylvilagus floridanus and Oryctolagus cuniculus) natural models (Christensen et al., 2017). More recently new models have been developed in mice and multi-mammate rats (Christensen et al., 2017). Anogenital lesions including neoplasia are described in humans and are associated predominantly to HPV-16 and HPV-18 (Howley et al., 2013). Amongst animal papillomaviruses, Rhesus papillomavirus (RhPV) and potentially baboon (Papio hamadryas anubis) papillomaviruses can be sexually transmitted between monkeys and can be associated to the development of cervical neoplasia (Bergin et al., 2013; Wood et al., 2007). HPV-16 and RhPV are very similar and macaque can make a good natural model for the study of HPV pathogenesis and for the development of preventive and therapeutic approaches. 
Only one report has been published regarding porcine papillomaviruses (Stevens et al., 2008). These porcine viruses are not fully characterized yet and their potential pathogenicity needs to be determined. Thus, it is too early to appreciate the potential interest of the swine model for human papillomaviruses.

\section{Human immunodeficiency virus 1 and 2}

Infections with HIV-1 and -2 cause the Acquired Immune Deficiency Syndrome (AIDS). This disease continues to be a major public health issue despite continuous progress in its management (Goff, 2013; Kuritzkes and Koup, 2013). The infection is characterized by a slow and progressive destruction of $\mathrm{CD}^{+}$T-cells leading finally to fatal immunosuppression. Even if the last years have seen great progress in the understanding of HIV infection and AIDS, there are still challenges, particularly the development of vaccines, new therapeutic approaches and resolution of HIV-induced inflammation. A limitation in HIV research is the lack of a totally suitable animal model. Natural models such as the rhesus macaques being infected by the Simian immunodeficiency virus (SIV) and humanized mice develop a disease that is similar to AIDS in humans (Evans and Silvestri, 2013; Garcia-Tellez et al., 2016; Victor Garcia, 2016). So far rhesus macaques/SIV model is the best model as it meets the conditions required to constitute a reliable animal model for a human infectious disease (Garcia-Tellez et al., 2016): (i) The pathogen causing a disease in the model should cause a disease similar to the disease caused by the human pathogen in humans; (ii) The course of the disease in the animals should resemble that in humans; (iii) Cells, tissues, and organs involved in the pathogenesis should be similar in the model and humans; (iv) Immune response to infection in the model should be similar to its counterpart in humans. All these conditions are not fulfilled in other animal models, i.e. Feline immunodeficiency virus in the cat and HIV in humanized mice (Garcia-Tellez et al., 2016). Thus, currently, non-human 
primates and humanized mice are the only animals able to model correctly the pathogenesis of HIV (Garcia-Tellez et al., 2016; Victor Garcia, 2016).

There is no naturally occurring Retroviridae similar to HIV in the pig preventing the development of experimental model in this species to study HIV. The only virus with some similarities in terms of pathogenicity to HIV in the pig would be the Porcine reproductive and respiratory syndrome virus (PRRSV), a member of the Arteriviridae family (Lunney et al., 2016). However, there are many differences between the two viruses limiting the interest of PRRSV as a natural model to study HIV.

\section{DEVELOPMENTS IN THE PORCINE TOOLBOX - STANDARDS AND NEW POSSIBILITIES}

The usefulness of an animal model for biomedical research depends highly on the availability of the appropriate tools to analyze the host-pathogen interactions. Due to the smaller market for biomedical research in pigs, it is understandable that the porcine toolbox is still not comparable to mice. Nevertheless, there were major developments in the porcine biomedical toolbox during the past ten years leading to major improvements in analyzing the host-pathogen interactions in pigs and the use of the pig as an animal model for studying human diseases including STIs. The following section provides an overview on the current standards and new developments for the porcine toolbox and their implications for studying human STIs.

\section{The porcine genome}

The Swine Genome Sequencing Consortium initiated the sequencing of the porcine genome in 2003 (Schook et al., 2005). Nearly a decade later, the reference genome sequence 
of pigs was published in Nature (Groenen et al., 2012). In the meanwhile, the genome sequences of several pig breeds are available inclusive the Göttingen minipig (Groenen, 2016). Annotations of the porcine genome are steadily growing and with the establishment of the "DGIL Porcine Translational Research Database" this year, swine researchers have a powerful, searchable database at hand (Dawson et al., 2017). It consists of currently $>13,000$ gene entries with 9,165 full-length RNA transcripts and 8,099 full-length protein sequences, corresponding to $41.7 \%$ and $42.6 \%$ of estimated genome coverage, respectively. In addition to the gene sequence and homology to humans, the database provides information on available primer and probe sequences, antibodies and other data on analyzing the gene of interest. Thereby, this database facilitates basic and translational research on every level.

\section{Genome editing in vitro and in vivo}

Since the first description of the function of Clustered Regularly Interspaced Short Palindromic Repeats (CRISPR) a decade ago (Barrangou et al., 2007), this bacterial "adaptive immune system" against bacteriophages came a long way and revolutionized bacterial and eukaryotic genome editing (Barrangou and Horvath, 2017). In 2012, the CRISPR/Cas9 system was used the first time to edit the human genome (Cong et al., 2013; Mali et al., 2013). Only one year later, Tan et al. used CRISPR/Cas9 to manipulate the genome of livestock inclusive pigs (Tan et al., 2013). In 2015, the CRISPRdirect software allowed the simple design of guide RNAs, which directs the CRISPR/Cas9 system to the target gene (Naito et al., 2015). The database of the software includes porcine gene sequences facilitating the use of CRISPR/Cas9 in pigs. Thereby, CRISPR/Cas makes genome editing widely available for the porcine research community. Currently, this technology is used for molecular biology analyses in vitro, e.g. to study the role of apoptosis-inducing molecule p53 in an infection with the Porcine circovirus type 2 (Xu et al., 2016). In vivo, the CRISPR/Cas9 was 
used to generate CD163 knockout pigs (Burkard et al., 2017). Since CD163 is the receptor for PRRSV, these pigs were resistant to PRRSV, the economically most important infectious disease for pig production worldwide (Burkard et al., 2017). In addition, ambitious researchers use the CRISPR/Cas9 system to generate immune deficient pigs (Sper and Piedrahita, manuscript in preparation). Final goal of this project is to populate these pigs with human immune cells to generate humanized pigs for biomedical research (https://projectreporter.nih.gov/project_info_description.cfm?aid=9384776\&icde=35976755). Thereby, the CRISPR/Cas9 system could even improve the biological relevance for studying human diseases inclusive STIs and holds extensive potential for the future of the porcine model.

\section{Characterization of the porcine immune response}

An important goal of biomedical research is to provide a comprehensive understanding of the immune response to infection. Therefore, the better the immunological toolbox to study infection and immunity in an animal model is, the more relevant is the model. The technology to detect pathogen-specific antibodies in enzyme-linked immunosorbent assay (ELISA) and neutralizing antibodies by various methods have been available in swine for decades and are still valuable and up-to-date tools to study the porcine humoral immune response (Bøje et al., 2016; Käser et al., 2017). Studying the cellular immune response on the other hand was rather limited for a long time in swine but the last decade brought some major developments. With the increased annotation coverage of the porcine genome, more immune targets became available for qPCR mRNA expression analysis (Dawson et al., 2017). The development of multiplex qPCR further optimized the system by facilitating high-throughput qPCR analysis, especially for limited sample volumes (Duvigneau et al., 2005). In addition, multiplexed cytokine and chemokine protein analysis 
was established (Bjerre et al., 2009) and became commercially available from several providers, further improving the former standard cytokine and chemokine ELISAs.

While these developments certainly improved the porcine toolbox, the main development was the establishment of $\mathrm{pFCM}$ for swine. At the beginning of the millennium, due to a lack of fluorochrome-conjugated antibodies detecting porcine antigens, FCM analysis required an indirect staining strategy limiting porcine FCM to mainly three colors (Saalmüller et al., 2002). Due to the increased popularity of the porcine model over the past years, the industry started to offer fluorochrome-antibody conjugation kits and fluorochrome-labeled antibodies for pigs. This development enabled the use of pFCM for pigs and facilitated a much more in-depth analysis of the cellular immune response. To date, $\mathrm{pFCM}$ has provided a better and more detailed understanding of the phenotype, maturation and differentiation of porcine innate immune cells, B cells, NK cells and T-cells (Braun et al., 2017; Summerfield et al., 2015a; Talker et al., 2013). In addition, pFCM improved the functional analysis of these cells by combining phenotypic analyses with the production of important cytokines as interleukin (IL-) 2, IL-4, IL-17, IFN- $\gamma$, and TNF- $\alpha$ (Käser et al., 2017; Talker et al., 2016). This improvement has major benefits for the study of infectious diseases as STIs if combined with a system to detect pathogen-specific immune cells. The recent developments in nextgeneration MHC(SLA)-typing (Sørensen et al., 2017), neural network-based prediction of SLA-binding peptides (Nielsen and Andreatta, 2016; Welner et al., 2017) and recombinant expression of SLA class I molecules for peptide-specific staining of reactive $\mathrm{CD}^{+} \mathrm{T}$-cells using tetramers, allow for detailed studies of cell-mediated immune responses against pathogens in pig models (Baratelli et al., 2017). Besides tetramer staining, pathogen-specific immune cells can be detected by pFCM upon in vitro restimulation of immune cells with pathogen antigens like peptides, proteins, whole-cell lysates, or by co-culturing of immune cells with infected host cells like epithelial cells. Thereby, we can determine which immune 
cell subset is involved in an immune response against a pathogen, analyze how much and which immune modulators these cells produce, and into which subset of memory immune cells they develop. This combined analysis allows the detection of multifunctional T-cells ( $\mathrm{T}_{\text {multi) }}$ (Käser et al., 2017; Talker et al., 2016), and central and effector memory cells $\left(\mathrm{T}_{\mathrm{CM}}\right.$

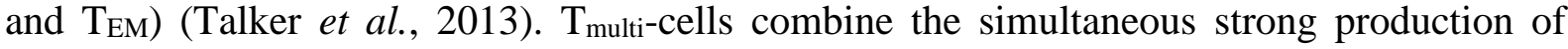
multiple cytokines with a long lifespan. They can frequent lymph nodes as well as the periphery, thereby integrating characteristics of $\mathrm{T}_{\mathrm{CM}}$ and $\mathrm{T}_{\mathrm{EM}}$, respectively (Seder et al., 2008). Due to their versatile effector function and migration potential, and their long lifespan,

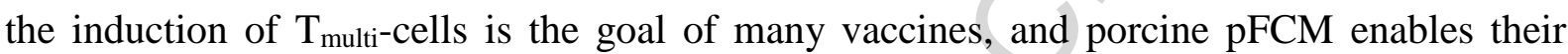
detection in pigs.

These developments provide access to gene and protein sequence information, stateof-the-art immunological tools for genome modification, and a comprehensive characterization of the immune response and the induction of immunological memory upon infection and vaccination in pigs. In combination with the high biological relevance, these developments make the pig a very valuable large animal model for studying human STIs as well as for other infections.

\section{CONCLUSIONS}

So far the swine model has been successful in the study of several human STIs. However, as presented in this review there is potential to further develop it. New technologies such as CRISPR/Cas9, offering convenient, fast, and reliable methods to refine animal models, and pFCM enabling a comprehensive analysis of the host immune response to infection, will most probably boost the swine model in the next decades.

\section{REFERENCES}


Abraham, M.C., Desjardins, M., Filion, L.G., Garber, G.E., 1996. Inducible immunity to Trichomonas vaginalis in a mouse model of vaginal infection. Infect. Immun. 64, 3571-5.

Afonina, G., Leduc, I., Nepluev, I., Jeter, C., Routh, P., Almond, G., Orndorff, P.E., Hobbs, M., Elkins, C., 2006. Immunization with the Haemophilus ducreyi Hemoglobin Receptor HgbA Protects against Infection in the Swine Model of Chancroid. Infect. Immun. 74, 2224-2232. doi:10.1128/IAI.74.4.2224-2232.2006

Allweiss, L., Dandri, M., 2016. Experimental in vitro and in vivo models for the study of human hepatitis B virus infection. J. Hepatol. 64, S17-S31. doi:10.1016/j.jhep.2016.02.012

Aravantinou, M., Frank, I., Arrode-Bruses, G., Szpara, M., Grasperge, B., Blanchard, J., Gettie, A., Derby, N., Martinelli, E., 2017. A model of genital herpes simplex virus Type 1 infection in Rhesus Macaques. J. Med. Primatol. 46, 121-128. doi:10.1111/jmp.12293

Arko, R.J., 1989. Animal models for pathogenic Neisseria species. Clin. Microbiol. Rev. 2 Suppl, S56-9.

Bara, M.R., McGowan, M.R., O’Boyle, D., Cameron, R.D., 1993. A study of the microbial flora of the anterior vagina of normal sows during different stages of the reproductive cycle. Aust. Vet. J. 70, 256-9.

Baratelli, M., Pedersen, L.E., Trebbien, R., Larsen, L.E., Jungersen, G., Blanco, E., Nielsen, J., Montoya, M., 2017. Identification of cross-reacting T-cell epitopes in structural and non-structural proteins of swine and pandemic H1N1 influenza A virus strains in pigs. J. Gen. Virol. 98, 895-899. doi:10.1099/jgv.0.000748

Barrangou, R., Fremaux, C., Deveau, H., Richards, M., Boyaval, P., Moineau, S., Romero, D.A., Horvath, P., 2007. CRISPR Provides Acquired Resistance Against Viruses in Prokaryotes. Science (80-. ). 315, 17091712. doi:10.1126/science. 1138140

Barrangou, R., Horvath, P., 2017. A decade of discovery: CRISPR functions and applications. Nat. Microbiol. 2, 17092. doi:10.1038/nmicrobiol.2017.92

Bergin, I.L., Bell, J.D., Chen, Z., Zochowski, M.K., Chai, D., Schmidt, K., Culmer, D.L., Aronoff, D.M., Patton, D.L., Mwenda, J.M., Wood, C.E., Burk, R.D., 2013. Novel Genital Alphapapillomaviruses in Baboons (Papio hamadryas Anubis) With Cervical Dysplasia. Vet. Pathol. 50, 200-208. doi:10.1177/0300985812439725

Bernard, H.-U., Burk, R.D., Chen, Z., van Doorslaer, K., Hausen, H. zur, de Villiers, E.-M., 2010. Classification of papillomaviruses (PVs) based on 189 PV types and proposal of taxonomic amendments. Virology 401, 70-79. doi:10.1016/j.virol.2010.02.002

Bjerre, M., Hansen, T.K., Flyvbjerg, A., Tønnesen, E., 2009. Simultaneous detection of porcine cytokines by 
multiplex analysis: development of magnetic bioplex assay. Vet. Immunol. Immunopathol. 130, 53-8. doi:10.1016/j.vetimm.2009.01.007

Bode, G., Clausing, P., Gervais, F., Loegsted, J., Luft, J., Nogues, V., Sims, J., Steering Group of the RETHINK Project, 2010. The utility of the minipig as an animal model in regulatory toxicology. J. Pharmacol. Toxicol. Methods 62, 196-220. doi:10.1016/j.vascn.2010.05.009

Bøje, S., Olsen, A.W., Erneholm, K., Agerholm, J.S., Jungersen, G., Andersen, P., Follmann, F., 2016. A multisubunit Chlamydia vaccine inducing neutralizing antibodies and strong IFN- $\gamma+$ CMI responses protects against a genital infection in minipigs. Immunol. Cell Biol. 94, 185-195. doi:10.1038/icb.2015.79

Booker, S.S., Jayanetti, C., Karalak, S., Hsiu, J.G., Archer, D.F., 1994. The effect of progesterone on the accumulation of leukocytes in the human endometrium. Am. J. Obstet. Gynecol. 171, 139-42.

Bosio, C., MacLeod, M., Marrack, P., Kedl, R., 2012. Utility of Mouse Models in Vaccine Design and Development, in: Morrow, W., Sheikh, N., Schmidt, C., Davies, D. (Eds.), Vaccinology: Principles and Practice. Blackwell Publishing Ltd, Published Online: 20 JUN 2012 03:25AM EST, pp. 94-109.

Braun, R.O., Python, S., Summerfield, A., 2017. Porcine B Cell Subset Responses to Toll-like Receptor Ligands. Front. Immunol. 8, 1044. doi:10.3389/fimmu.2017.01044

Breshears, L.M., Edwards, V.L., Ravel, J., Peterson, M.L., 2015. Lactobacillus crispatus inhibits growth of Gardnerella vaginalis and Neisseria gonorrhoeae on a porcine vaginal mucosa model. BMC Microbiol. 15, 276. doi:10.1186/s12866-015-0608-0

Burkard, C., Lillico, S.G., Reid, E., Jackson, B., Mileham, A.J., Ait-Ali, T., Whitelaw, C.B.A., Archibald, A.L., 2017. Precision engineering for PRRSV resistance in pigs: Macrophages from genome edited pigs lacking CD163 SRCR5 domain are fully resistant to both PRRSV genotypes while maintaining biological function. PLoS Pathog. 13, e1006206. doi:10.1371/journal.ppat.1006206

Butler, J.E., Brown, W.R., 1994. The immunoglobulins and immunoglobulin genes of swine. Vet. Immunol. Immunopathol. 43, 5-12.

Cerutti, A., 2008. The regulation of IgA class switching. Nat. Rev. Immunol. 8, 421-434.

Chapwanya, A., Usman, A.Y., Irons, P.C., 2016. Comparative aspects of immunity and vaccination in human and bovine trichomoniasis: a review. Trop. Anim. Health Prod. 48, 1-7. doi:10.1007/s11250-015-0909-1

Christensen, N.D., Budgeon, L.R., Cladel, N.M., Hu, J., 2017. Recent advances in preclinical model systems for papillomaviruses. Virus Res. 231, 108-118. doi:10.1016/j.virusres.2016.12.004

Coers, J., Gondek, D.C., Olive, A.J., Rohlfing, A., Taylor, G.A., Starnbach, M.N., 2011. Compensatory T cell 
responses in IRG-deficient mice prevent sustained Chlamydia trachomatis infections. PLoS Pathog. 7, e1001346. doi:10.1371/journal.ppat.1001346

Cong, L., Ran, F.A., Cox, D., Lin, S., Barretto, R., Habib, N., Hsu, P.D., Wu, X., Jiang, W., Marraffini, L.A., Zhang, F., 2013. Multiplex Genome Engineering Using CRISPR/Cas Systems. Science (80-. ). 339, 819823. doi:10.1126/science.1231143

Corbeil, L.B., 1995. Use of an animal model of trichomoniasis as a basis for understanding this disease in women. Clin. Infect. Dis. 21 Suppl 2, S158-61.

Corpus Luteum [WWW Document], 2015.

Darbellay, J., Lai, K., Babiuk, S., Berhane, Y., Ambagala, A., Wheler, C., Wilson, D., Walker, S., Potter, A., Gilmour, M., Safronetz, D., Gerdts, V., Karniychuk, U., 2017. Neonatal pigs are susceptible to experimental Zika virus infection. Emerg. Microbes Infect. 6, e6. doi:10.1038/emi.2016.133

Darville, T., Hiltke, T.J., 2010. Pathogenesis of genital tract disease due to Chlamydia trachomatis. J Infect Dis 201 Suppl, S114-25.

Dawson, H.D., Chen, C., Gaynor, B., Shao, J., Urban, J.F., 2017. The porcine translational research database: a manually curated, genomics and proteomics-based research resource. BMC Genomics 18, 643. doi:10.1186/s12864-017-4009-7

de Jonge, M.I., Keizer, S.A.S., el Moussaoui, H.M., van Dorsten, L., Azzawi, R., van Zuilekom, H.I., Peters, P.P.W., van Opzeeland, F.J.H., van Dijk, L., Nieuwland, R., Roosenboom-Theunissen, H.W.M., Vrijenhoek, M.P., Debyser, I., Verweij, P.J.M., van Duijnhoven, W.G.F., van den Bosch, J.F., Nuijten, P.J.M., 2011. A novel guinea pig model of Chlamydia trachomatis genital tract infection. Vaccine 29, 5994-6001. doi:10.1016/j.vaccine.2011.06.037

de la Maza, L.M., Pal, S., Khamesipour, A., Peterson, E.M., 1994. Intravaginal inoculation of mice with the Chlamydia trachomatis mouse pneumonitis biovar results in infertility. Infect. Immun. 62, 2094-7.

Dean, D., Rothschild, J., Ruettger, A., Kandel, R.P., Sachse, K., 2013. Zoonotic Chlamydiaceae Species Associated with Trachoma, Nepal. Emerg. Infect. Dis. 19, 1948-1955. doi:10.3201/eid1912.130656

De Puysseleyr, L., De Puysseleyr, K., Braeckman, L., Morré, S.A., Cox, E., Vanrompay, D., 2017. Assessment of Chlamydia suis Infection in Pig Farmers. Transbound. Emerg. Dis. 64, 826-833. doi:10.1111/tbed.12446

Denayer, T., Stöhr, T., Van Roy, M., 2014. Animal models in translational medicine: Validation and prediction. New Horizons Transl. Med. 2, 5-11. doi:10.1016/J.NHTM.2014.08.001 
Desjardins, M., Filion, L.G., Robertson, S., Cameron, D.W., 1995. Inducible immunity with a pilus preparation booster vaccination in an animal model of Haemophilus ducreyi infection and disease. Infect. Immun. 63, 2012-20.

Desjardins, M., Filion, L.G., Robertson, S., Kobylinski, L., Cameron, D.W., 1996. Evaluation of humoral and cell-mediated inducible immunity to Haemophilus ducreyi in an animal model of chancroid. Infect. Immun. 64, 1778-88.

Duvigneau, J.C., Hartl, R.T., Groiss, S., Gemeiner, M., 2005. Quantitative simultaneous multiplex real-time PCR for the detection of porcine cytokines. J. Immunol. Methods 306, 16-27. doi:10.1016/j.jim.2005.06.021

Edwards, J.L., Brown, E.J., Ault, K.A., Apicella, M.A., 2001. The role of complement receptor 3 (CR3) in Neisseria gonorrhoeae infection of human cervical epithelia. Cell. Microbiol. 3, 611-22.

Edwards, J.L., Brown, E.J., Uk-Nham, S., Cannon, J.G., Blake, M.S., Apicella, M.A., 2002. A co-operative interaction between Neisseria gonorrhoeae and complement receptor 3 mediates infection of primary cervical epithelial cells. Cell. Microbiol. 4, 571-84.

Erneholm, K., Lorenzen, E., Bøje, S., Olsen, A.W., Andersen, P., Cassidy, J.P., Follmann, F., Jensen, H.E., Agerholm, J.S., 2016. Genital tract lesions in sexually mature Göttingen minipigs during the initial stages of experimental vaginal infection with Chlamydia trachomatis serovar D. BMC Vet. Res. 12, 200. doi:10.1186/s12917-016-0793-6

Eurell, J.A., Frappier, B.L., 2006. Dellmann's Textbook of Veterinary Histology. Blackwell Publishing, United States of America.

Evans, D.T., Silvestri, G., 2013. Nonhuman primate models in AIDS research. Curr. Opin. HIV AIDS 8, 1. doi:10.1097/COH.0b013e328361cee8

Fairbairn, L., Kapetanovic, R., Sester, D.P., Hume, D.A., 2011. The mononuclear phagocyte system of the pig as a model for understanding human innate immunity and disease. J. Leukoc. Biol 6, 855-871.

Farage, M.A., W, M.K., D, S.J., 2010. Dynamics of the vaginal ecosystem - hormonal influences. Infect Dis Res Treat $3,1-15$.

Farris, C.M., Morrison, R.P., 2011. Vaccination against Chlamydia Genital Infection Utilizing the Murine C. muridarum Model. Infect. Immun. 79, 986-996. doi:10.1128/IAI.00881-10

Fulcher, R.A., Cole, L.E., Janowicz, D.M., Toffer, K.L., Fortney, K.R., Katz, B.P., Orndorff, P.E., Spinola, S.M., Kawula, T.H., 2006. Expression of Haemophilus ducreyi Collagen Binding Outer Membrane Protein NcaA Is Required for Virulence in Swine and Human Challenge Models of Chancroid. Infect. Immun. 74, 
2651-2658. doi:10.1128/IAI.74.5.2651-2658.2006

Garcia-Tellez, T., Huot, N., Ploquin, M.J., Rascle, P., Jacquelin, B., Müller-Trutwin, M., 2016. Non-human primates in HIV research: Achievements, limits and alternatives. Infect. Genet. Evol. 46, 324-332. doi:10.1016/j.meegid.2016.07.012

Gerdts, V., Wilson, H.L., Meurens, F., Van den Hurk, S.V.D.L., Wilson, D., Walker, S., Wheler, C., Townsend, H., Potter, A.A., 2015. Large animal models for vaccine development and testing. ILAR J. 56, 53-62. doi:10.1093/ilar/ilv009

Goff, S.P., 2013. Retroviridae, in: Knipe, D.M., Howley, P.M. (Eds.), Fields Virology Sixth Edition. Philadelphia, USA, pp. 1424-1473.

González-Beiras, C., Marks, M., Chen, C.Y., Roberts, S., Mitjà, O., 2016. Epidemiology of Haemophilus ducreyi Infections. Emerg. Infect. Dis. 22, 1-8. doi:10.3201/eid2201.150425

Gottlieb, S.L., Johnston, C., 2016. Future prospects for new vaccines against sexually transmitted infections. Curr. Opin. Infect. Dis. 30, 1. doi:10.1097/QCO.0000000000000343

Groenen, M.A., Archibald, A.L., Uenishi, H., Tuggle, C.K., Takeuchi, Y., Rothschild, M.F., Rogel-Gaillard, C., Park, C., Milan, D., Megens, H.J., Li, S., Larkin, D.M., Kim, H., Frantz, L.A., Caccamo, M., Ahn, H., Aken, B.L., Anselmo, A., Anthon, C., Auvil, L., Badaoui, B., Beattie, C.W., Bendixen, C., Berman, D., Blecha, F., Blomberg, J., Bolund, L., Bosse, M., Botti, S., Bujie, Z., Bystrom, M., Capitanu, B., CarvalhoSilva, D., Chardon, P., Chen, C., Cheng, R., Choi, S.H., Chow, W., Clark, R.C., Clee, C., Crooijmans, R.P., Dawson, H.D., Dehais, P., De Sapio, F., Dibbits, B., Drou, N., Du, Z.Q., Eversole, K., Fadista, J., Fairley, S., Faraut, T., Faulkner, G.J., Fowler, K.E., Fredholm, M., Fritz, E., Gilbert, J.G., Giuffra, E., Gorodkin, J., Griffin, D.K., Harrow, J.L., Hayward, A., Howe, K., Hu, Z.L., Humphray, S.J., Hunt, T., Hornshoj, H., Jeon, J.T., Jern, P., Jones, M., Jurka, J., Kanamori, H., Kapetanovic, R., Kim, J., Kim, J.H., Kim, K.W., Kim, T.H., Larson, G., Lee, K., Lee, K.T., Leggett, R., Lewin, H.A., Li, Y., Liu, W., Loveland, J.E., Lu, Y., Lunney, J.K., Ma, J., Madsen, O., Mann, K., Matthews, L., McLaren, S., Morozumi, T., Murtaugh, M.P., Narayan, J., Nguyen, D.T., Ni, P., Oh, S.J., Onteru, S., Panitz, F., Park et al., E.W., 2012. Analyses of pig genomes provide insight into porcine demography and evolution. Nature 491, 393-398.

Groenen, M.A.M., 2016. A decade of pig genome sequencing: a window on pig domestication and evolution.

Genet. Sel. Evol. 48, 23. doi:10.1186/s12711-016-0204-2

Gu, A., Zhang, Z., Zhang, N., Tsark, W., Shively, J.E., 2010. Generation of Human CEACAM1 Transgenic 
Mice and Binding of Neisseria Opa Protein to Their Neutrophils. PLoS One 5, e10067. doi:10.1371/journal.pone.0010067

Gutierrez, K., Dicks, N., Glanzner, W.G., Agellon, L.B., Bordignon, V., 2015. Efficacy of the porcine species in biomedical research. Front. Genet. 6, 293. doi:10.3389/fgene.2015.00293

Harper, K., Knauf, S., 2013. Treponema pallidum in primates: Clinical manifestations, epidemiology, and evolution of a stealthy pathogen, in: Brinkworth, J.F., Pechenkina, K. (Eds.), Primates, Pathogens, and Evolution. Developments in Primatology: Progress and Prospects. Springer, New York, USA, pp. 189_219.

Henning, T.R., Butler, K., Hanson, D., Sturdevant, G., Ellis, S., Sweeney, E.M., Mitchell, J., Deyounks, F., Phillips, C., Farshy, C., Fakile, Y., Papp, J., Evan Secor, W., Caldwell, H., Patton, D., McNicholl, J.M., N. Kersh, E., 2014. Increased Susceptibility to Vaginal Simian/Human Immunodeficiency Virus Transmission in Pig-tailed Macaques Coinfected With Chlamydia trachomatis and Trichomonas vaginalis. J. Infect. Dis. 210, 1239-1247. doi:10.1093/infdis/jiu240

Hill, S.A., Masters, T.L., Wachter, J., 2016. Gonorrhea - an evolving disease of the new millennium. Microb. Cell 3, 371-389. doi:10.15698/mic2016.09.524

Hobbs, M.M., San Mateo, L.R., Orndorff, P.E., Almond, G., Kawula, T.H., 1995. Swine model of Haemophilus ducreyi infection. Infect. Immun. 63, 3094-100.

Hook, E.W., 2017. Syphilis. Lancet 389, 1550-1557. doi:10.1016/S0140-6736(16)32411-4

Howley, P.M., Schiller, J.T., Lowy, D.R., 2013. Papillomaviruses, in: Knipe, D.M., Howley, P.M. (Eds.), Fields Virology Sixth Edition. Philadelphia, USA, pp. 1662-1703.

Hussein, A.M., Newby, T.J., Stokes, C.R., Bourne, F.J., 1983. Quantitation and origin of immunoglobulins A, G and $\mathrm{M}$ in the secretions and fluids of the reproductive tract of the sow. J. Reprod. Immunol. 5, 17-26.

Jensen, J.S., Cusini, M., Gomberg, M., Moi, H., 2016. 2016 European guideline on Mycoplasma genitalium infections. J. Eur. Acad. Dermatology Venereol. 30, 1650-1656. doi:10.1111/jdv.13849

Jerse, A.E., Wu, H., Packiam, M., Vonck, R.A., Begum, A.A., Garvin, L.E., 2011. Estradiol-Treated Female Mice as Surrogate Hosts for Neisseria gonorrhoeae Genital Tract Infections. Front. Microbiol. 2, 107.

Jiwakanon, J., Persson, E., Kaeoket, K., Dalin, A.-M., 2005. The Sow Endosalpinx at Different Stages of the Oestrous Cycle and at Anoestrus: Studies on Morphological Changes and Infiltration by Cells of the Immune System. Reprod. Domest. Anim. 40, 28-39. doi:10.1111/j.1439-0531.2004.00550.x

Kaeoket, K., Persson, E., Dalin, A.-M., 2002. Erratum: The sow endometrium at different stages of the oestrus 
cycle: Studies on morphological changes and infiltration by cells of the immune system (Animal Reproduction Science (2001) 65(95-114)PII:S0378432000002116). Anim. Reprod. Sci. 73, 89-107.

Källström, H., Blackmer Gill, D., Albiger, B., Liszewski, M.K., Atkinson, J.P., Jonsson, A.B., 2001. Attachment of Neisseria gonorrhoeae to the cellular pilus receptor CD46: identification of domains important for bacterial adherence. Cell. Microbiol. 3, 133-43.

Kallstrom, H., Liszewski, M.K., Atkinson, J.P., Jonsson, A.B., Källström, H., Liszewski, M.K., Atkinson, J.P., Jonsson, A.B., Kallstrom, H., Liszewski, M.K., Atkinson, J.P., Jonsson, A.B., 1997. Membrane cofactor protein (MCP or CD46) is a cellular pilus receptor for pathogenic Neisseria. Mol. Microbiol. 25, 639-647.

Kapoor, A., Simmonds, P., Scheel, T.K.H., Hjelle, B., Cullen, J.M., Burbelo, P.D., Chauhan, L. V., Duraisamy, R., Sanchez Leon, M., Jain, K., Vandegrift, K.J., Calisher, C.H., Rice, C.M., Lipkin, W.I., 2013. Identification of Rodent Homologs of Hepatitis C Virus and Pegiviruses. MBio 4, e00216-13-e00216-13. doi:10.1128/mBio.00216-13

Käser, T., Pasternak, J.A., Delgado-Ortega, M., Hamonic, G., Lai, K., Erickson, J., Walker, S., Dillon, J.R., Gerdts, V., Meurens, F., 2017. Chlamydia suis and Chlamydia trachomatis induce multifunctional CD4 T cells in pigs. Vaccine 35, 91-100. doi:10.1016/j.vaccine.2016.11.050

Kissinger, P., 2015. Trichomonas vaginalis: a review of epidemiologic, clinical and treatment issues. BMC Infect. Dis. 15, 307. doi:10.1186/s12879-015-1055-0

Klymiuk, N., Seeliger, F., Bohlooly-Y, M., Blutke, A., Rudmann, D.G., Wolf, E., 2016. Tailored Pig Models for Preclinical Efficacy and Safety Testing of Targeted Therapies. Toxicol. Pathol. 44, 346-57. doi:10.1177/0192623315609688

Kollias, C.M., Huneke, R.B., Wigdahl, B., Jennings, S.R., 2015. Animal models of herpes simplex virus immunity and pathogenesis. J. Neurovirol. 21, 8-23. doi:10.1007/s13365-014-0302-2

Konar, H., 2014. DC Dutta's Textbook of Obstetrics, DC Dutta's Textbook of Obstetrics. Jaypee Brothers Medical Publishers Ltd., New Delhi.

König, H.E., G, L.H., 2009. Anatomie Der Haussäugetiere. Schattauer, Stuttgart.

Krause, W.J., 2005. Krause's Essential Human Histology For Medical Students. Universal Publishers, United States of America.

Kuritzkes, D.R., Koup, R.A., 2013. HIV-1: Pathogenesis, Clinical Manifestations, and Treatment, in: Knipe, D.M., Howley, P.M. (Eds.), Fields Virology Sixth Edition. Philadelphia, USA, pp. 1561-1583.

Kutteh, W.H., Prince, S.J., Hammond, K.R., Kutteh, C.C., Mestecky, J., 1996. Variations in immunoglobulins 
and IgA subclasses of human uterine cervical secretions around the time of ovulation. Clin. Exp. Immunol. $104,538-42$.

Lankau, E.W., Turner, P. V, Mullan, R.J., Galland, G.G., 2014. Use of nonhuman primates in research in North America. J. Am. Assoc. Lab. Anim. Sci. 53, 278-82.

Lempp, F.A., Wiedtke, E., Qu, B., Roques, P., Chemin, I., Vondran, F.W.R., Le Grand, R., Grimm, D., Urban, S., 2017. Sodium taurocholate cotransporting polypeptide is the limiting host factor of hepatitis B virus infection in macaque and pig hepatocytes. Hepatology. doi:10.1002/hep.29112

Looker, K.J., Magaret, A.S., May, M.T., Turner, K.M.E., Vickerman, P., Gottlieb, S.L., Newman, L.M., $2015 a$. Global and Regional Estimates of Prevalent and Incident Herpes Simplex Virus Type 1 Infections in 2012. PLoS One 10, e0140765. doi:10.1371/journal.pone.0140765

Looker, K.J., Magaret, A.S., Turner, K.M.E., Vickerman, P., Gottlieb, S.L., Newman, L.M., 2015b. Global estimates of prevalent and incident herpes simplex virus type 2 infections in 2012. PLoS One 10, e114989. doi:10.1371/journal.pone.0114989

Looker, K.J., Magaret, A.S., Turner, K.M.E., Vickerman, P., Gottlieb, S.L., Newman, L.M., 2015c. Correction: Global estimates of prevalent and incident herpes simplex virus type 2 infections in 2012. PLoS One 10, e0128615. doi:10.1371/journal.pone.0128615

Lorenzen, E., Follmann, F., Bøje, S., Erneholm, K., Olsen, A.W., Agerholm, J.S., Jungersen, G., Andersen, P., 2015a. Intramuscular Priming and Intranasal Boosting Induce Strong Genital Immunity Through Secretory IgA in Minipigs Infected with Chlamydia trachomatis. Front. Immunol. 6, 628. doi:10.3389/fimmu.2015.00628

Lorenzen, E., Follmann, F., Jungersen, G., Agerholm, J.S., 2015b. A review of the human vs. porcine female genital tract and associated immune system in the perspective of using minipigs as a model of human genital Chlamydia infection. Vet. Res. 46, 116. doi:10.1186/s13567-015-0241-9

Lorenzen, E., Follmann, F., Secher, J.O., Goericke-Pesch, S., Hansen, M.S., Zakariassen, H., Olsen, A.W., Andersen, P., Jungersen, G., Agerholm, J.S., 2017. Intrauterine inoculation of minipigs with Chlamydia trachomatis during diestrus establishes a longer lasting infection compared to vaginal inoculation during estrus. Microbes Infect. 19, 334-342. doi:10.1016/j.micinf.2017.01.008

Lossi, L., D’Angelo, L., De Girolamo, P., Merighi, A., 2016. Anatomical features for an adequate choice of experimental animal model in biomedicine: II. Small laboratory rodents, rabbit, and pig. Ann. Anat. Anat. Anzeiger 204, 11-28. doi:10.1016/j.aanat.2015.10.002 
Lunney, J.K., Fang, Y., Ladinig, A., Chen, N., Li, Y., Rowland, B., Renukaradhya, G.J., 2016. Porcine Reproductive and Respiratory Syndrome Virus (PRRSV): Pathogenesis and Interaction with the Immune System. Annu. Rev. Anim. Biosci. 4, 129-154. doi:10.1146/annurev-animal-022114-111025

Makarova, N., Henning, T., Taylor, A., Dinh, C., Lipscomb, J., Aubert, R., Hanson, D., Phillips, C., Papp, J., Mitchell, J., McNicholl, J., Garcia-Lerma, G.J., Heneine, W., Kersh, E., Dobard, C., 2017. Topical tenofovir protects against vaginal simian HIV infection in macaques coinfected with Chlamydia trachomatis and Trichomonas vaginalis. AIDS 31, 745-752. doi:10.1097/QAD.0000000000001389

Mali, P., Yang, L., Esvelt, K.M., Aach, J., Guell, M., DiCarlo, J.E., Norville, J.E., Church, G.M., 2013. RNAGuided Human Genome Engineering via Cas9. Science 339, 823-826. doi:10.1126/science.1232033

Manhart, L.E., 2017. Mycoplasma genitalium on the Loose. Sex. Transm. Dis. 44, $463-465$. doi:10.1097/OLQ.0000000000000665

Mather, E.C., Day, B.N., Watson, B.W., Straw, J.A., Fabor, S., Trout, H.F., 1977. "In vivo" pH values of the estrous reproductive tract of the gilt. Theriogenology 8, 323-327. doi:10.1016/0093-691X(77)90184-4

McGowin, C.L., Spagnuolo, R.A., Pyles, R.B., 2010. Mycoplasma genitalium Rapidly Disseminates to the Upper Reproductive Tracts and Knees of Female Mice following Vaginal Inoculation. Infect. Immun. 78, 726-736. doi:10.1128/IAI.00840-09

McShane, H., Williams, A., 2014. A review of preclinical animal models utilised for TB vaccine evaluation in the context of recent human efficacy data. Tuberculosis 94, 105-110. doi:10.1016/j.tube.2013.11.003

Mesalam, A., Vercauteren, K., Meuleman, P., 2016. Mouse Systems to Model Hepatitis C Virus Treatment and Associated Resistance. Viruses 8, 176. doi:10.3390/v8060176

Mestecky, J., Raska, M., Novak, J., Alexander, R.C., Moldoveanu, Z., 2010. Antibody-mediated protection and the mucosal immune system of the genital tract: relevance to vaccine design. J. Reprod. Immunol. 85, 8185. doi:10.1016/j.jri.2010.02.003

Meurens, F., Summerfield, A., Nauwynck, H., Saif, L., Gerdts, V., 2012. The pig: a model for human infectious diseases. Trends Microbiol 20, 50-57. doi:10.1016/j.tim.2011.11.002

Meysick, K.C., Garber, G.E., 1992. Interactions between Trichomonas vaginalis and vaginal flora in a mouse model. J. Parasitol. 78, 157-60.

Miyairi, I., Ramsey, K.H., Patton, D.L., 2010. Duration of untreated chlamydial genital infection and factors associated with clearance: review of animal studies. J. Infect. Dis. 201 Suppl, S96-103. doi:10.1086/652393 
Morgan, C.A., Lukehart, S.A., Van Voorhis, W.C., 2002. Immunization with the N-terminal portion of Treponema pallidum repeat protein $\mathrm{K}$ attenuates syphilitic lesion development in the rabbit model. Infect. Immun. 70, 6811-6.

Mount, D.T., Bigazzi, P.E., Barron, A.L., 1972. Infection of genital tract and transmission of ocular infection to newborns by the agent of guinea pig inclusion conjunctivitis. Infect. Immun. 5, 921-6.

Naito, Y., Hino, K., Bono, H., Ui-Tei, K., 2015. CRISPRdirect: software for designing CRISPR/Cas guide RNA with reduced off-target sites. Bioinformatics 31, 1120-3. doi:10.1093/bioinformatics/btu743

Nelson, D.E., Virok, D.P., Wood, H., Roshick, C., Johnson, R.M., Whitmire, W.M., Crane, D.D., SteeleMortimer, O., Kari, L., McClarty, G., Caldwell, H.D., 2005. Chlamydial IFN- immune evasion is linked to host infection tropism. Proc. Natl. Acad. Sci. 102, 10658-10663. doi:10.1073/pnas.0504198102

Newman, L., Rowley, J., Vander Hoorn, S., Wijesooriya, N.S., Unemo, M., Low, N., Stevens, G., Gottlieb, S., Kiarie, J., Temmerman, M., 2015. Global Estimates of the Prevalence and Incidence of Four Curable Sexually Transmitted Infections in 2012 Based on Systematic Review and Global Reporting. PLoS One 10, e0143304. doi:10.1371/journal.pone.0143304

Ngampasutadol, J., Tran, C., Gulati, S., Blom, A.M., Jerse, E.A., Ram, S., Rice, P.A., 2008. Species-specificity of Neisseria gonorrhoeae infection: do human complement regulators contribute? Vaccine 26 Suppl 8, I62-6

Nickel, R., Schummer, A., Seiferle, E., 1979. The Viscera of the Domestic Mammals, in: Schummer, A., Nickel, R. (Eds.), The Viscera of the Domestic Mammals. Verlag Paul Parey; 2nd Revised edition, BerlinHamburg, p. 403

Nielsen, M., Andreatta, M., 2016. NetMHCpan-3.0; improved prediction of binding to MHC class I molecules integrating information from multiple receptor and peptide length datasets. Genome Med. 8, 33. doi:10.1186/s13073-016-0288-X

Nogal-Ruiz, J.J., Gómez-Barrio, A., Escario, J.A., Martínez-Fernández, A.R., 2003. Effect of Anapsos® in a murine model of experimental trichomoniasis. Parasite 10, 303-308. doi:10.1051/parasite/2003104303

Nogal-Ruiz, J.J., Gómez-Barrio, A., Escario, J.A., Montero-Pereira, D., Martínez-Fernández, A.R., 2005. Effect of piroxicam, metamizol, and S-adenosylmethionine in a murine model of experimental trichomoniasis. Parasite 12, 79-83. doi:10.1051/parasite/2005121079

Nogal Ruiz, J.., Escario, J.A., Martinez Diaz, R.., Gomez Barrio, A., 1997. Evaluation of a murine model of experimental trichomoniasis. Parasite 4, 127-132. doi:10.1051/parasite/1997042127 
Parr, M.B., Parr, E.L., 2003. Vaginal immunity in the HSV-2 mouse model. Int. Rev. Immunol. 22, 43-63.

Patton, D.L., 1985. Immunopathology and histopathology of experimental chlamydial salpingitis. Rev. Infect.

Dis. 7, 746-53.

Pellett, P.E., Roizman, B., 2013. Herpesviridae, in: Knipe, D.M., Howley, P.M. (Eds.), Fields Virology Sixth Edition. Philadelphia, USA, pp. 1802-1822.

Peng, X., Knouse, J.A., Hernon, K.M., 2015. Rabbit Models for Studying Human Infectious Diseases. Comp. Med. 65, 499-507.

Pradines, B., Bories, C., Vauthier, C., Ponchel, G., Loiseau, P.M., Bouchemal, K., 2015. Drug-Free Chitosan Coated Poly(isobutylcyanoacrylate) Nanoparticles Are Active Against Trichomonas vaginalis and NonToxic Towards Pig Vaginal Mucosa. Pharm. Res. 32, 1229-1236. doi:10.1007/s11095-014-1528-7

Priedkalns, J., Leiser, R., 2006. Female reproductive system, in: Eurell, J., Frappier, B.L. (Eds.), Dellmann’s Textbook of Veterinary Histology 6th Ed. Blackwell Publishing Ltd, Ames, Iowa, pp. 254-278.

Protzer, U., 2017. Viral hepatitis: The bumpy road to animal models for HBV infection. Nat. Rev. Gastroenterol. Hepatol. 14, 327-328. doi:10.1038/nrgastro.2017.44

Quayle, A.J., 2002. The innate and early immune response to pathogen challenge in the female genital tract and the pivotal role of epithelial cells. J. Reprod. Immunol. 57, 61-79.

Radzio, J., Henning, T., Jenkins, L., Ellis, S., Farshy, C., Phillips, C., Holder, A., Kuklenyik, S., Dinh, C., Hanson, D., McNicholl, J., Heneine, W., Papp, J., Kersh, E.N., García-Lerma, J.G., 2016. Combination Emtricitabine and Tenofovir Disoproxil Fumarate Prevents Vaginal Simian/Human Immunodeficiency Virus Infection in Macaques Harboring Chlamydia trachomatis and Trichomonas vaginalis. J. Infect. Dis. 213, 1541-1545. doi:10.1093/infdis/jiw002

Ramsay, J.D., Evanoff, R., Wilkinson, T.E., Divers, T.J., Knowles, D.P., Mealey, R.H., 2015. Experimental transmission of equine hepacivirus in horses as a model for hepatitis C virus. Hepatology 61, 1533-1546. doi:10.1002/hep.27689

Ramsey, K.H., Miranpuri, G.S., Poulsen, C.E., Marthakis, N.B., Braune, L.M., Byrne, G.I., 1998. Inducible nitric oxide synthase does not affect resolution of murine chlamydial genital tract infections or eradication of chlamydiae in primary murine cell culture. Infect. Immun. 66, 835-8.

Rank, R.G., White, H.J., Hough, A.J., Pasley, J.N., Barron, A.L., 1982. Effect of estradiol on chlamydial genital infection of female guinea pigs. Infect. Immun. 38, 699-705.

Rank, R.G., Whittum- Hudson, J.A., 2010. Protective Immunity to Chlamydial Genital Infection: Evidence from 
Animal Studies. J. Infect. Dis. 201, 168-177. doi:10.1086/652399

Riviere, G.R., Thomas, D.D., Cobb, C.M., 1989. In vitro model of Treponema pallidum invasiveness. Infect. Immun. 57, 2267-71.

Rogers, C.S., 2016. Genetically engineered livestock for biomedical models. Transgenic Res. 25, 345-359. doi:10.1007/s11248-016-9928-6

Rogers, C.S., Abraham, W.M., Brogden, K.A., Engelhardt, J.F., Fisher, J.T., McCray Jr., P.B., McLennan, G., Meyerholz, D.K., Namati, E., Ostedgaard, L.S., Prather, R.S., Sabater, J.R., Stoltz, D.A., Zabner, J., Welsh, M.J., 2008. The porcine lung as a potential model for cystic fibrosis. Am. J. Physiol. Lung Cell Mol. Physiol. 295, L240-63.

Roizman, B., Knipe, D.M., Whitley, R.J., 2013. Herpes Simplex Viruses, in: Knipe, D.M., Howley, P.M. (Eds.), Fields Virology Sixth Edition. Philadelphia, USA, pp. 1823-1897.

Russell, M.W., Mestecky, J., 2002. Humoral immune responses to microbial infections in the genital tract. Microbes Infect. 4, 667-77.

Saalmüller, A., Werner, T., Fachinger, V., 2002. T-helper cells from naive to committed. Vet. Immunol. Immunopathol. 87, 137-45.

Sadarangani, M., Pollard, A.J., Gray-Owen, S.D., 2011. Opa proteins and CEACAMs: pathways of immune engagement for pathogenic Neisseria. FEMS Microbiol. Rev. 35, 498-514. doi:10.1111/j.15746976.2010.00260.x

Satterwhite, C.L., Torrone, E., Meites, E., Dunne, E.F., Mahajan, R., Ocfemia, M.C., Su, J., Xu, F., Weinstock, H., 2013. Sexually Transmitted Infections Among US Women and Men: Prevalence and Incidence Estimates, 2008. Sex Transm Dis 40, 187-193.

Schautteet, K., De Clercq, E., Jönsson, Y., Lagae, S., Chiers, K., Cox, E., Vanrompay, D., 2012. Protection of pigs against genital Chlamydia trachomatis challenge by parenteral or mucosal DNA immunization. Vaccine 30, 2869-2881. doi:10.1016/j.vaccine.2012.02.044

Schautteet, K., Stuyven, E., Beeckman, D.S., Van Acker, S., Carlon, M., Chiers, K., Cox, E., Vanrompay, D., 2011a. Protection of pigs against Chlamydia trachomatis challenge by administration of a MOMP-based DNA vaccine in the vaginal mucosa. Vaccine 29, 1399-1407.

Schautteet, K., Stuyven, E., Cox, E., Vanrompay, D., 2011b. Validation of the Chlamydia trachomatis genital challenge pig model for testing recombinant protein vaccines. J Med Microbiol 60, 117-127.

Schautteet, K., Vanrompay, D., 2011. Chlamydiaceae infections in pig. Vet Res 42, 29. 
Schomberg, D.T., Tellez, A., Meudt, J.J., Brady, D.A., Dillon, K.N., Arowolo, F.K., Wicks, J., Rousselle, S.D., Shanmuganayagam, D., 2016. Miniature Swine for Preclinical Modeling of Complexities of Human Disease for Translational Scientific Discovery and Accelerated Development of Therapies and Medical Devices. Toxicol. Pathol. 44, 299-314. doi:10.1177/0192623315618292

Schook, L.B., Beever, J.E., Rogers, J., Humphray, S., Archibald, A., Chardon, P., Milan, D., Rohrer, G., Eversole, K., 2005. Swine Genome Sequencing Consortium (SGSC): a strategic roadmap for sequencing the pig genome. Comp. Funct. Genomics 6, 251-5. doi:10.1002/cfg.479

Seder, R.A., Darrah, P.A., Roederer, M., 2008. T-cell quality in memory and protection: implications for vaccine design. Nat. Rev. Immunol. 8, 247-258. doi:10.1038/nri2274

Senger, P.L., 2005. Pathways to Pregnancy and Parturition. Current Conceptions Inc, Washington DC, USA.

Shah, A.A., Schripsema, J.H., Imtiaz, M.T., Sigar, I.M., Kasimos, J., Matos, P.G., Inouye, S., Ramsey, K.H., 2005. Histopathologic changes related to fibrotic oviduct occlusion after genital tract infection of mice with Chlamydia muridarum. Sex. Transm. Dis. 32, 49-56.

Silverthorn, D.U., 2007. Human Physiology. Pearson Benjamin Cummings, United States of America.

Smith, J.D., Garber, G.E., 2015. Trichomonas vaginalis Infection Induces Vaginal CD4 + T-Cell Infiltration in a Mouse Model: A Vaccine Strategy to Reduce Vaginal Infection and HIV Transmission. J. Infect. Dis. 212, 285-293. doi:10.1093/infdis/jiv036

Snoeck, V., Peters, I.R., Cox, E., 2006. The IgA system: a comparison of structure and function in different species. Vet. Res. 37, 455-467. doi:10.1051/vetres:2006010

Sørensen, M.R., Ilsøe, M., Strube, M.L., Bishop, R., Erbs, G., Hartmann, S.B., Jungersen, G., 2017. SequenceBased Genotyping of Expressed Swine Leukocyte Antigen Class I Alleles by Next-Generation Sequencing Reveal Novel Swine Leukocyte Antigen Class I Haplotypes and Alleles in Belgian, Danish, and Kenyan Fattening Pigs and Göttingen Minipigs. Front. Immunol. 8, 701. doi:10.3389/fimmu.2017.00701

Stevens, H., Rector, A., Van Der Kroght, K., Van Ranst, M., 2008. Isolation and cloning of two variant papillomaviruses from domestic pigs: Sus scrofa papillomaviruses type 1 variants a and b. J. Gen. Virol. 89, 2475-2481. doi:10.1099/vir.0.2008/003186-0

Strouhal, M., Smajs, D., Matejkova, P., Sodergren, E., Amin, A.G., Howell, J.K., Norris, S.J., Weinstock, G.M., 2007. Genome Differences between Treponema pallidum subsp. pallidum Strain Nichols and $T$. paraluiscuniculi Strain Cuniculi A. Infect. Immun. 75, 5859-5866. doi:10.1128/IAI.00709-07

Sturm, A.W., 1997. Iron and virulence of Haemophilus ducreyi in a primate model. Sex. Transm. Dis. 24, 64-8. 
Summerfield, A., Auray, G., Ricklin, M., 2015a. Comparative Dendritic Cell Biology of Veterinary Mammals. Annu. Rev. Anim. Biosci. 3, 533-557. doi:10.1146/annurev-animal-022114-111009

Summerfield, A., Meurens, F., Ricklin, M.E., 2015b. The immunology of the porcine skin and its value as a model for human skin. Mol. Immunol. 66, 14-21. doi:10.1016/j.molimm.2014.10.023

Svartström, O., Karlsson, F., Fellström, C., Pringle, M., 2013. Characterization of Treponema spp. isolates from pigs with ear necrosis and shoulder ulcers. Vet. Microbiol. 166, 617-623. doi:10.1016/j.vetmic.2013.07.005

Swindle, M.M., Makin, A., Herron, A.J., Clubb Jr., F.J., Frazier, K.S., 2012. Swine as models in biomedical research and toxicology testing. Vet. Pathol. 49, 344-356.

Talker, S.C., Kaser, T., Reutner, K., Sedlak, C., Mair, K.H., Koinig, H., Graage, R., Viehmann, M., Klingler, E., Ladinig, A., Ritzmann, M., Saalmuller, A., Gerner, W., 2013. Phenotypic maturation of porcine NK- and T-cell subsets. Dev. Comp. Immunol. 40, 51-68.

Talker, S.C., Stadler, M., Koinig, H.C., Mair, K.H., Rodríguez-Gómez, I.M., Graage, R., Zell, R., Dürrwald, R., Starick, E., Harder, T., Weissenböck, H., Lamp, B., Hammer, S.E., Ladinig, A., Saalmüller, A., Gerner, W., 2016. Influenza A Virus Infection in Pigs Attracts Multifunctional and Cross-Reactive T Cells to the Lung. J. Virol. 90, 9364-82. doi:10.1128/JVI.01211-16

Tan, W., Carlson, D.F., Lancto, C.A., Garbe, J.R., Webster, D.A., Hackett, P.B., Fahrenkrug, S.C., 2013. Efficient nonmeiotic allele introgression in livestock using custom endonucleases. Proc. Natl. Acad. Sci. 110, 16526-16531. doi:10.1073/pnas.1310478110

Tantalo, L.C., Lukehart, S.A., Marra, C.M., 2005. Treponema pallidum Strain-Specific Differences in Neuroinvasion and Clinical Phenotype in a Rabbit Model. J. Infect. Dis. 191, 75-80. doi:10.1086/426510

Taylor-Robinson, D., Furr, P.M., Tully, J.G., Barile, M.F., Møller, B.R., 1987. Animal models of Mycoplasma genitalium urogenital infection. Isr. J. Med. Sci. 23, 561-4.

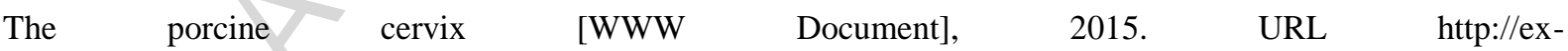
epsilon.slu.se:8080/archive/00003222/01/EEF_Karin_Edstrom.pdf (accessed 5.6.15).

Totten, P.A., Morton, W.R., Knitter, G.H., Clark, A.M., Kiviat, N.B., Stamm, W.E., 1994. A primate model for chancroid. J. Infect. Dis. 169, 1284-90.

Tuffrey, M., Falder, P., Taylor-Robinson, D., 1982. Genital-tract infection and disease in nude and immunologically competent mice after inoculation of a human strain of Chlamydia trachomatis. Br. J. Exp. Pathol. 63, 539-46. 
Tully, J.G., Taylor-Robinson, D., Cole, R.M., Rose, D.L., 1981. A newly discovered mycoplasma in the human urogenital tract. Lancet (London, England) 1, 1288-91.

Unemo, M., Bradshaw, C.S., Hocking, J.S., de Vries, H.J.C., Francis, S.C., Mabey, D., Marrazzo, J.M., Sonder, G.J.B., Schwebke, J.R., Hoornenborg, E., Peeling, R.W., Philip, S.S., Low, N., Fairley, C.K., 2017. Sexually transmitted infections: challenges ahead. Lancet Infect. Dis. 17, e235-e279. doi:10.1016/S14733099(17)30310-9

Vandegrift, K.J., Critchlow, J.T., Kapoor, A., Friedman, D.A., Hudson, P.J., 2017. Peromyscus as a model system for human hepatitis C: An opportunity to advance our understanding of a complex host parasite system. Semin. Cell Dev. Biol. 61, 123-130. doi:10.1016/j.semcdb.2016.07.031

Vanrompay, D., Hoang, T.Q., De Vos, L., Verminnen, K., Harkinezhad, T., Chiers, K., Morre, S.A., Cox, E., 2005. Specific-pathogen-free pigs as an animal model for studying Chlamydia trachomatis genital infection. Infect. Immun. 73, 8317-8321.

Vela, A.I., Collins, M.D., Lawson, P.A., García, N., Domínguez, L., Fernández-Garayzábal, J.F., 2005. Uruburuella suis gen. nov., sp. nov., isolated from clinical specimens of pigs. Int. J. Syst. Evol. Microbiol. 55, 643-647. doi:10.1099/ijs.0.63346-0

Victor Garcia, J., 2016. Humanized mice for HIV and AIDS research. Curr. Opin. Virol. 19, 56-64. doi:10.1016/j.coviro.2016.06.010

Welner, S., Nielsen, M., Rasmussen, M., Buus, S., Jungersen, G., Larsen, L.E., 2017. Prediction and in vitro verification of potential CTL epitopes conserved among PRRSV-2 strains. Immunogenetics. doi:10.1007/s00251-017-1004-8

Whitelaw, C.B.A., Sheets, T.P., Lillico, S.G., Telugu, B.P., 2016. Engineering large animal models of human disease. J. Pathol. 238, 247-56. doi:10.1002/path.4648

Wicher, V., Wicher, K., Abbruscato, F., Auger, I., Rudofsky, U., 1999. The Time-Dependent Clearance of Virulent Treponema pallidum in Susceptible and Resistant Strains of Guinea Pigs Is Significantly Different. Clin. Immunol. 91, 77-83. doi:10.1006/clim.1998.4672

Wiesenfeld, H.C., Manhart, L.E., 2017. Mycoplasma genitalium in Women: Current Knowledge and Research Priorities for This Recently Emerged Pathogen. J. Infect. Dis. 216, S389-S395. doi:10.1093/infdis/jix198

Wittmann, G., Rziha, H.J., 1989. Aujeszky’s disease (pseudorabies) in pigs, in: Wittmann, G. (Ed.), Herpesvirus Diseases of Cattle, Horses and Pigs. Boston, USA, pp. 230-235.

Wolner-Hanssen, P., Patton, D.L., Holmes, K.K., 1991. Protective immunity in pig-tailed macaques after 
cervical infection with Chlamydia trachomatis. Sex. Transm. Dis. 18, 21-5.

Wood, C.E., Chen, Z., Cline, J.M., Miller, B.E., Burk, R.D., 2007. Characterization and Experimental Transmission of an Oncogenic Papillomavirus in Female Macaques. J. Virol. 81, 6339-6345. doi:10.1128/JVI.00233-07

Wood, G.E., Patton, D.L., Cummings, P.K., Iverson-Cabral, S.L., Totten, P.A., 2017. Experimental Infection of Pig-Tailed Macaques (Macaca nemestrina) with Mycoplasma genitalium. Infect. Immun. 85, e00738-16. doi:10.1128/IAI.00738-16

Wrobel, K., Bergman, M., 2006. Male Reproductive System, in: Eurell, J.A., Frappier, B.L. (Eds.), Dellmann's Textbook of Veterinary Histology 6th Ed. Blackwell Publishing Ltd, Ames, Iowa, pp. 233-255.

Xu, D., Du, Q., Han, C., Wang, Z., Zhang, X., Wang, T., Zhao, X., Huang, Y., Tong, D., 2016. p53 signaling modulation of cell cycle arrest and viral replication in porcine circovirus type 2 infection cells. Vet. Res. 47, 120. doi:10.1186/s13567-016-0403-4

Yim, K.C., Carroll, C.J., Tuyama, A., Cheshenko, N., Carlucci, M.J., Porter, D.D., Prince, G.A., Herold, B.C., 2005. The Cotton Rat Provides a Novel Model To Study Genital Herpes Infection and To Evaluate Preventive Strategies. J. Virol. 79, 14632-14639. doi:10.1128/JVI.79.23.14632-14639.2005

Yu, H., Karunakaran, K.P., Kelly, I., Shen, C., Jiang, X., Foster, L.J., Brunham, R.C., 2011. Immunization with Live and Dead Chlamydia muridarum Induces Different Levels of Protective Immunity in a Murine Genital Tract Model: Correlation with MHC Class II Peptide Presentation and Multifunctional Th1 Cells. J. Immunol. 186, 3615-3621. doi:10.4049/jimmunol.1002952

Zhou, X., Bent, S.J., Schneider, M.G., Davis, C.C., Islam, M.R., Forney, L.J., 2004. Characterization of vaginal microbial communities in adult healthy women using cultivation-independent methods. Microbiology 150, 2565-73. doi:10.1099/mic.0.26905-0 


\section{Box 1: Advantages of pigs for STI vaccine development:}

- Availability: Important species for meat production ensures easy access to animals. Blood and various tissues as lymph nodes and genital tracts are byproducts and provide unlimited access to primary cells for in vitro analyses of infection and immunity.

- Susceptibility to pathogens: Pigs and humans share the susceptibility to several sexually transmitted infection (STI) pathogens including viruses as the hepatitis $\mathrm{E}$ virus and bacteria as Chlamydia sp. (Meurens et al., 2012; Lorenzen et al., 2015b).

- Affordable costs: Costs for a standard 3-week in vivo vaccine trial are with 20,000 USD very affordable compared to non-human primates, which can be ten times more expensive.

- Physiology: Pigs have a very similar physiology to humans including size, skin and mucosa, facilitating for example the determination of the optimal vaccine dosage and route of delivery including new methods of vaccine delivery as skin needle patches and mucosal vaccines (Gerdts et al., 2015; Meurens et al., 2012).

- Reproductive cycle: Pigs and humans have similar reproductive cycles even if pig cycle has a shorter duration (21 days vs. 28 days). This similarity is of high importance for testing vaccine candidates against STIs since hormones influence host susceptibility for a pathogen and the immune response in the genital tract (Lorenzen et al., 2015b).

- Immune system: The immune system of pigs is very similar to the human immune system facilitating the translation of results obtained on the immune response induced by a vaccine to humans (Meurens et al., 2012).

- Immunological toolbox: In order to correctly evaluate safety, efficacy and to find immune correlates of protection it is essential to be able to detect i) pathogen burden, ii) pathological changes and iii) the induced immune response with a focus on immunological memory. Protocols for detection of pathogens in pig samples are readily available using quantitative PCR (qPCR). Pathological changes in pigs can be determined either by expert evaluation of whole organs or by histology/immunohistochemistry. While the tools for analyzing the porcine immune response are not as sophisticated as for mice, there have been many improvements during the last years. Readily available analyses of the porcine immune response include the antigen-specific humoral immune response via detection of immunoglobulin (Ig) subclasses via ELISA and neutralizing antibodies analysis (e.g. via flow cytometry). A detailed analysis of the cellular immune response can be performed via qPCR as well as multi-color flow cytometry and includes important memory T-cell subsets as multifunctional T-cells ( $T$ ), central memory T-cells $\left(T_{C M}\right)$ and effector memory T-cells $\left(T_{E M}\right)$ for an optimal analysis of the induction of immunological memory (Käser et al., 2017; Talker et al., 2016). 
Table 1: Anatomical, physiological and immunological comparison of human and porcine female reproductive system

\begin{tabular}{|c|c|c|c|}
\hline & Human & Pig & Refs \\
\hline -Bicornual uterus & No & Yes & (König and G, 2009) \\
\hline -Length of the uterus $(\mathrm{cm})$ & 7 & 37 (minipig) & (Konar, 2014) \\
\hline -Cervical columnar epithelial cells & Yes & Almost absent & (Eurell and Frappier, 2006; Krause, 2005) \\
\hline -Length of reproductive cycle & 28 days & 19-21 days & $\begin{array}{l}\text { (Eurell and Frappier, 2006; Senger, 2005; } \\
\text { Silverthorn, 2007) }\end{array}$ \\
\hline -Endometrial sloughing (menses) & Yes & No & $\begin{array}{l}\text { (Bode et al., 2010; Senger, 2005; Swindle et al., } \\
\text { 2012) }\end{array}$ \\
\hline -Follicular phase hormones & LH, FSH, Estrogen & LH, FSH, Estrogen & $\begin{array}{l}\text { (Lorenzen et al., 2015b; Senger, 2005; Silverthorn, } \\
\text { 2007) }\end{array}$ \\
\hline -Luteal phase hormone & Progesterone & Progesterone & $\begin{array}{l}\text { (Lorenzen et al., 2015b; Senger, 2005; Silverthorn, } \\
\text { 2007) }\end{array}$ \\
\hline -Inducer of luteolysis & Ovarian PGF2 $\alpha$ & Uterine PGF2 $\alpha$ & (“Corpus Luteum," 2015) \\
\hline$-\mathrm{pH}$ in vagina & 3.5-5 (acidic) & $\sim 7$ (neutral) & $\begin{array}{l}\text { (Lorenzen et al., 2015b; Mather et al., 1977; } \\
\text { Quayle, 2002) }\end{array}$ \\
\hline $\begin{array}{l}\text {-High Lactobacillus \% in vaginal } \\
\text { flora }\end{array}$ & Yes & No & $\begin{array}{l}\text { (Bara et al., 1993; Farage et al., 2010; Lorenzen et } \\
\text { al., 2015b) }\end{array}$ \\
\hline -Dominant genital Ig isotype & $\lg G>\lg A 2>\lg A 1$ & IgG>IgA (no subtypes) & $\begin{array}{l}\text { (Butler and Brown, 1994; Cerutti, 2008; Mestecky } \\
\text { et al., 2010; Snoeck et al., 2006) }\end{array}$ \\
\hline $\begin{array}{l}\text {-Decreasing Ig levels around } \\
\text { ovulation }\end{array}$ & Yes & Yes & (Hussein et al., 1983; Kutteh et al., 1996) \\
\hline $\begin{array}{l}\text {-Genital mucosal lymphoid } \\
\text { aggregates }\end{array}$ & Yes & Yes & $\begin{array}{l}\text { (Russell and Mestecky, 2002; "The porcine cervix," } \\
\text { 2015) }\end{array}$ \\
\hline $\begin{array}{l}\text {-Influx of neutrophils in the } \\
\text { endometrium }\end{array}$ & $\begin{array}{l}\text { With progesterone in } \\
\text { luteal phase }\end{array}$ & $\begin{array}{l}\text { With estrogen } \\
\text { follicular phase }\end{array}$ & $\begin{array}{l}\text { (Booker et al., 1994; Hussein et al., 1983; } \\
\text { Jiwakanon et al., 2005; Kaeoket et al., 2002) }\end{array}$ \\
\hline
\end{tabular}

LH: Luteinizing hormone; FSH: Follicle stimulating hormone; PGF: Prostaglandin

Table 2: Anatomical comparison of human and porcine male reproductive system

\begin{tabular}{llll}
\hline & Human & Pig & Refs \\
\hline -Preputial diverticulum & No & Yes & $\begin{array}{l}\text { (Eurell and Frappier, 2006; König and G, } \\
\text {-Sigmoid flexure }\end{array}$ \\
& No & Yes & $\begin{array}{l}\text { 2009; Krause, 2005; Lossi et al., 2016; } \\
\text { Silverthorn, 2007; Swindle et al., 2012; } \\
\text { Wrobel and Bergman, 2006) }\end{array}$ \\
-Penis/prepuce epithelium & Squamous & Squamous \\
-Significant erectile tissue & Yes & No & \\
-Urethral epithelium & Pseudostratified columnar & Transitional \\
-Ampulla of ductus deferens & Present & Absent & \\
\hline
\end{tabular}

\section{Figure legends}

\section{Figure 1: Gross anatomy of the porcine female genital tract}

The long vagina $(\mathrm{V})$ is followed by the cervix $(\mathrm{C})$, the length of which is indicated by a bar. The urinary bladder $(\mathrm{U})$ is closely associated with the vagina. The cervix, the uterine corpus (UC) and segments of the uterine horns (UH) have been opened exposing an edematous mucosa (M). Notice the short uterine body that continues into two long uterine horns. The coiled Fallopian tubes (FT) can be seen extending from the tip of the uterine horns towards 
the ovaries and the ovarian bursa (B). The ovaries have been sectioned revealing multiple corpora lutea, which are easily assessed in the left ovary (LO). Bar $=5 \mathrm{~cm}$. Ten-month-old Göttingen minipig.

\section{Figure 2: Gross anatomy of the porcine male genital tract}

The preputial skin (PS) has been sectioned exposing the left preputial diverticle (PD) and the preputial mucosa (PR) that envelopes the free part of the penis (PE). Urine is oozing from the opened preputial diverticle (asterix). The length and location of the sigmoid flexure (SF) of the penis is indicated by a bar. The penis continues caudally into the bulb of the penis (BP) and is no longer visible as it continues under the accessory genital glands. In the male pig, these glands are dominated by the large bilateral, almost symmetrical bulbourethral glands (B) and the vesicular gland $(\mathrm{V})$. The prostate gland $(\mathrm{P})$ is relatively small and only a portion can be seen between the lobes of the vesicular gland. The vesicular gland is closely associated to the urinary bladder $(\mathrm{U})$. The spermatic cord has been opened exposing the ductus deferens (DD). The vaginal tunice of the right testis (RT) has been opened exposing the surface of the testis, the head (HE) and tail (TE) of the epididymis, while the tunice of the left testis (LT) is intact. Bar $=5 \mathrm{~cm}$. Nine-month-old Göttingen minipig.

Figure 3: Chlamydia trachomatis - animal models, pros and cons

Chlamydia: C; Lower Genital Tract: LGT; Major Outer Membrane Protein: MOMP; Interferon gamma: IFN- $\gamma$; Sexually Transmitted Infection: STI 


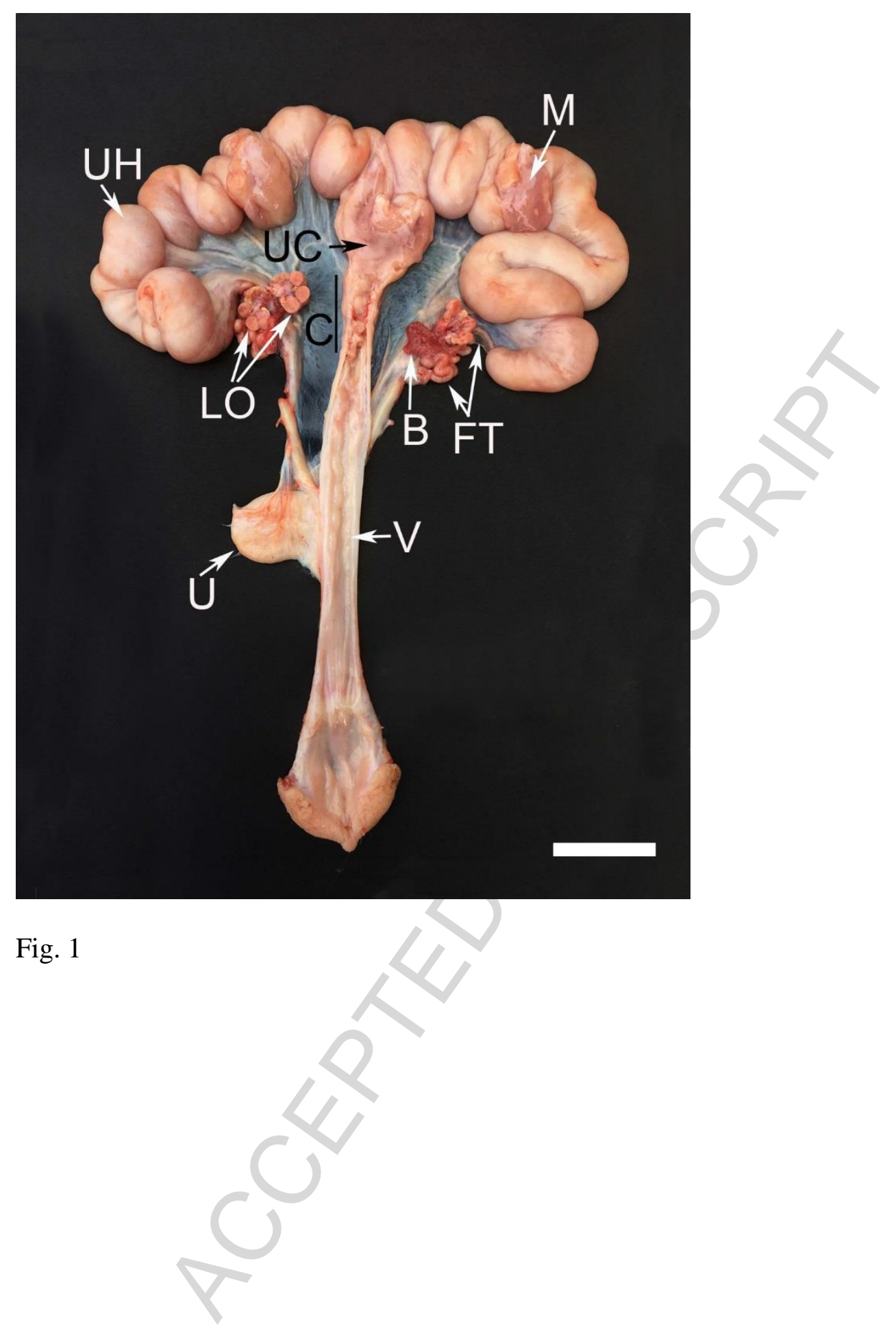




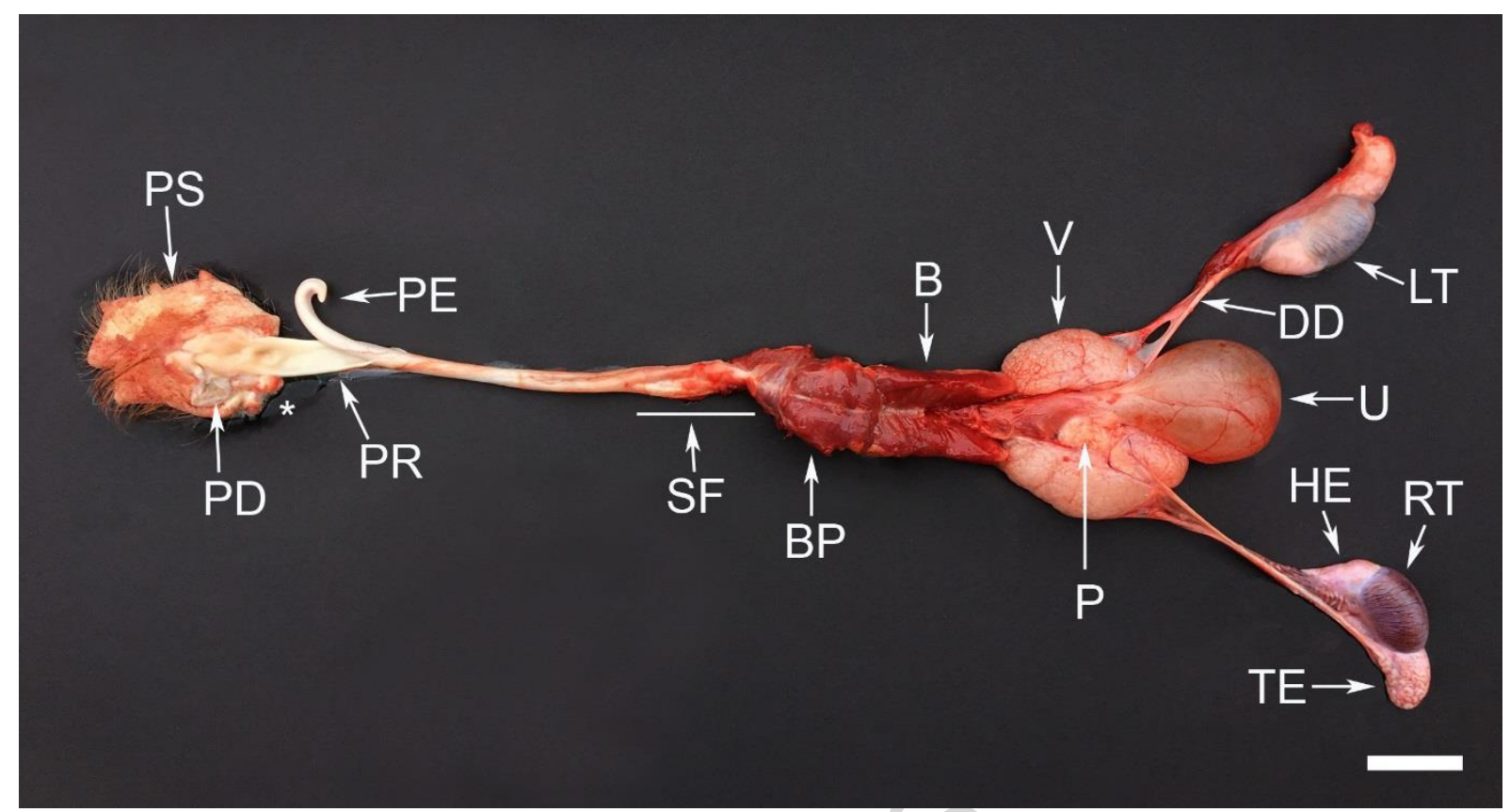

Fig. 2 


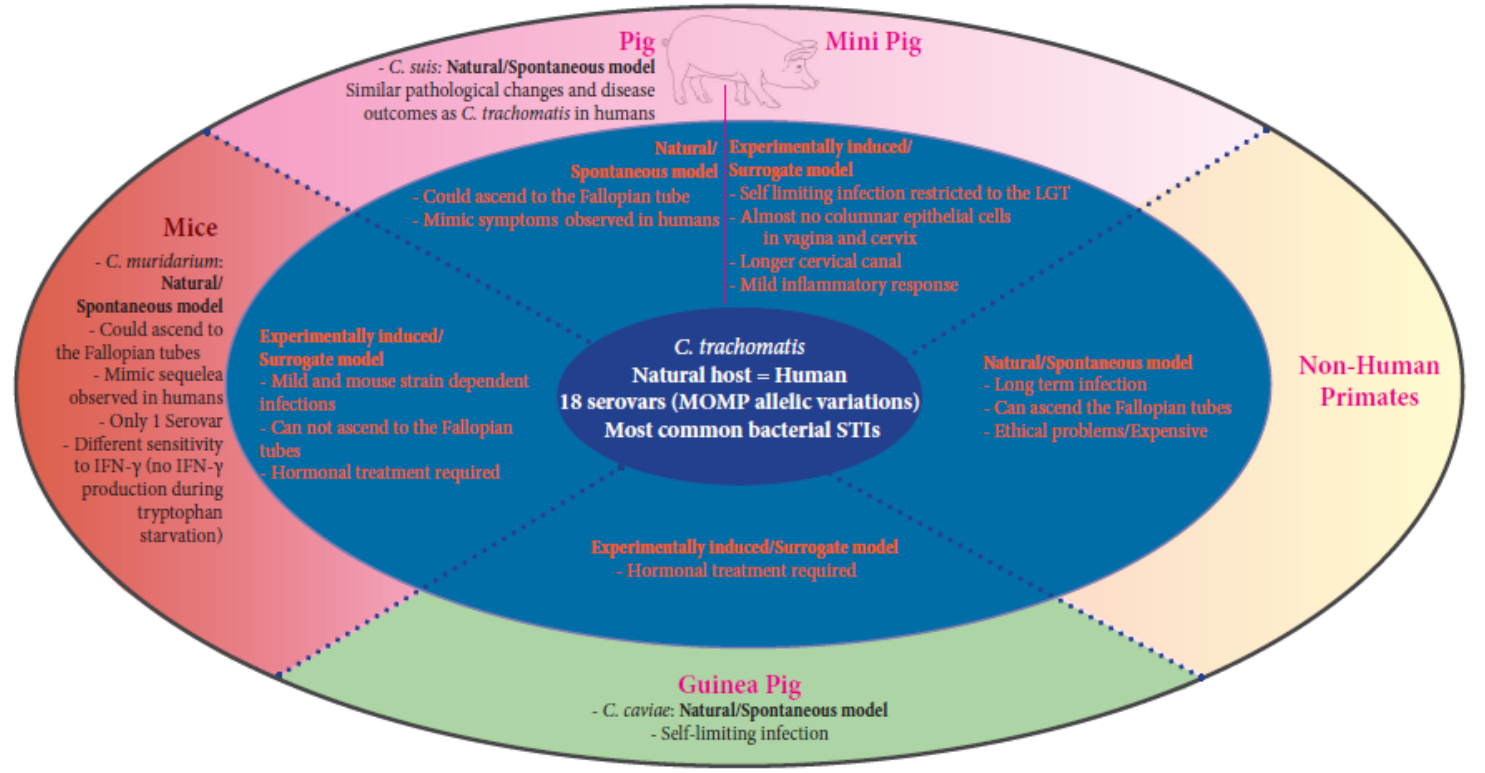

Fig. 3 


\section{Highlights}

-Pigs are being used as preclinical animal models for various human infections.

-The pig can be used for the study of male and female human sexually transmitted infections.

-They make surrogate or natural animal models to decipher Chlamydia trachomatis pathogenesis

-Human medical research needs alternative animal models that are more predictive.

-New technologies such as CRISPR-Cas9 open the doors to new exciting developments of the model. 